\title{
STUDIE
}

\section{SPRÁVNÍ MECHANISMY PŘESUNU KNIŽNÍCH FONDU゚ V LETECH 1918-1954: ODRAZOVÝ MŮSTEK K VÝZKUMU KNIŽNÍ PROVENIENCE*}

\author{
Marcela Sulženko - Luboš Kokeš (Praha)
}

\begin{abstract}
Administrative Mechanisms of the Transfer of Book Collections in 1918-1954: A Springboard for Research on Book Provenance
Abstract: The history of Czechoslovak private libraries reflected great historical events, specifically in the change of ownership between 1918 and $1945 / 1954$. The biggest change came after the Second World War, when the highest state officials decided to punish war criminals. In general, all Germans were labelled as enemies of the republic and were to bear collective guilt for starting the war. Their punishment included, among other things, the loss of property, which also concerned their libraries. This study focuses on the state administration dealing with such property.
\end{abstract}

Keywords: library history - book culture - confiscated property - Czechoslovakia - administration - cultural heritage

Překládaná studie si klade za cíl zmapovat správní aspekty související s majetkovými přesuny knižních fondů v českých zemích v letech 1918-1954. Ve sledovaném období počínaje vznikem Československa, přes skomírající státní suverenitu za druhé republiky a nacistické okupace, omezenou demokratickou soutěž a socializační trendy třetí republiky až po únorový komunistický státní převrat v roce 1948 a nástup totalitního režimu, proběhly několikeré zásahy do vlastnických vztahů, které se zásadním způsobem dotkly taktéž nakládání s rozsáhlými knižními soubory. Rok 1954 byl zvolen s ohledem na převzetí zámeckých knihoven do správy Národního muzea (dále jen často „NM“).

Hlavním předmětem zájmu jsou převážně soukromé knihovny - spjaté se šlechtickými sídly (zámecké knihovny) a ostatní knihovny z majetku konfiskovaného pro Československou republiku po druhé světové válce na základě dekretů prezidenta republiky (dobovou terminologií ,knihovny z bytů Němcü“, německých institucí ad.). Zahrnuty nejsou klášterní knihovny, které byly zajištěny po násilném zrušení klášterů v roce 1950 (akce „K“). Přestože by do sledovaného období jistě patřily, jejich správa se odvíjela v odlišné linii.

Autoři cílí na popsání majetkoprávní roviny, legislativy, správních mechanismů, jedinců či institucí, které se staly určujícími činiteli v procesech souvisejících se zajišt’ováním a redistribucí majetku natolik specifického, jakým knihovny bezesporu byly.

\section{8-1938}

„Zámky, jako sídla stavi̊, kdysi sociálně nejvýše stojících, a ještě v dobách nedávno minulých i politicky a hospodářsky nejsilnějšich, jsou kulturnimi dokumenty nejen doby svého vzniku, nýbrž i celého svého trvání. Bylo by jistě velkou kulturni škodou, kdyby při postupujicích změnách politického, hospodářského a sociálního života nebyla včas věnována dostatečná pozornost těmto svědkưm vzdělanosti nejvyšších vrstev bývalého, vlastního politického národa, které několik století dávaly ráz politickému, církevnímu, sociálnímu, hospodářrkému, vědeckému i uměleckému životu našich zemí. "1

Kulturní bohatství uložené v hradních, zámeckých a palácových knihovnách (dále jen ,zámecké knihovny“), vznikajících po několik staletí za účasti panovnického majestátu, šlechtické i církevní vrchnosti, řeholních řádů či lépe situovaných měšt'anů a podnikatelů 19. století, představovalo obrovské množství cenných pramenů vztahujících se k politickým, hospodářským a sociálním dějinám českých zemí. Z hlediska samotné šlechty se ve vlastnictví rozmanitých i specializovaných knižních sbírek odrážela humanistická touha po znalostech klasické antické historie, umocněná poznatky z kavalírských cest a prolnutá s vlastní básnickou či prozaickou tvorbou, dále četba Písma svatého, sběratelská vášeň, výchova potomstva a reprezentace zračící se v řadě monumentálních interiérových knihoven barokní éry a období „dlouhého“

\footnotetext{
* Text příspěvku je jedním z výstupů projektu Virtuální rekonstrukce rozptýlených provenienčně bohemikálních knižních celků v tuzemských i zahraničních knihovnách (DG18P02OVV009) financovaného Ministerstvem kultury ČR v rámci Programu na podporu aplikovaného výzkumu a experimentálního vývoje národní a kulturní identity (NAKI II).

1 KREJČÍK 1922, s. 9.
} 
19. století. Bourrlivé společensko-politické události „krátkého“ 20. století, eskalující ve dvou světových válkách a rozdělení světa tzv. železnou oponou, se zásadním způsobem odrazily také v nakládání $\mathrm{s}$ knižním a archivním dědictvím uloženým na vrchnostenských zámcích, jejichž majitelé definitivně ztratili dřívější výsadní politické postavení včetně velké části majetku či práv s ním disponovat.

Po první světové válce proběhly např́č Evropou rozsáhlé státoprávní změny a majetkové transformace, které se zásadním způsobem dotkly také někdejšího šlechtického majetku. Ve spojení se špatnými ekonomickými poměry meziválečné Evropy se tyto přeměny odrazily také v majetkových poměrech některých šlechtických rodů a jejich zámeckých knihoven. Závažným celoevropským jevem se v této souvislosti stal „boom“ rozprodejů či aukcí starobylých biblioték. , Válka změnila poměry. Stejně jako velké umělecké sbirky, zlato a drahokamy, objevily se na trhu i knihy, o nichž již dávno nebylo slechu. Před nékolika lety, za ménové krize v Německu, přešla leckterá kniha přes hranice Německa; před nedávnou dobou přišla na řadu Anglie, kde vysoké daně nutily k prodejüm; dnes zase pád franku zpuisobi snad odliv knih z Francie [...]. " 2 Ze světově proslulých knižních komplexů se rozprodeje týkaly např. bohaté knihovny říšsského rodu Stolbergů ve Wernigerode (Sasko-Anhaltsko), liturgických knižních sbírek vévody Roberta I. Parmského (1848-1907) či knihovny ruských carů z Carského Sela. ${ }^{3}$

Demokratický režim nově vzniklého Československa se rozhodl rozejít se symboly někdejšího habsburského soustátí, především pak s jeho elitami, ${ }^{4}$ což se projevilo již v prosinci 1918 ve zrušení ,šlechtictví, řádů a titulư‘“ ${ }^{5} \mathrm{~K}$ zániku milované monarchie a ztráty šlechtického raison d'etre se přidaly také rozsáhlé majetkové přesuny související s pozemkovou reformou, jejíž osten míril proti institutu a majetkové podstatě fideikomisů („svěřenství“ - definitivně zrušeny v r. 1924), velkostatkům (500 až 2000 ha) a latifundiím (nad 2000 ha), v drtivé míře spravovanými šlechtou a katolickou církví. V důsledku „největšího díla české revoluce“, „dovršení národního obrození“ či „odčinění Bílé hory“, jak byla pozemková reforma $\mathrm{v}$ dobovém kontextu označována (a již tehdy také namnoze kritizována pro svůj př́liš „,revoluční charakter“6), bylo v několika vlnách v letech 1919 až 1935 v českých zemích zabráno a přerozděleno Státním pozemkovým úruadem (SPÚ) 1283286 ha půdy zemědělské a 2738331 ha půdy nezemědělské, ${ }^{7}$ přičemž reforma nebyla nikdy zcela dokončena a po druhé světové válce došlo k její revizi. Vlastníkům zabraného majetku byla, pokud možno dle jejich uvážení, přidělena výměra půdy nepřesahující minimální hodnotu státem určeného záboru, tj. ve výši maximálně 150 ha zemědělské a 250 ha nezemědělské půdy s přesahem v odůvodněných prrípadech. ${ }^{8}$ SPÚ mohl zabranou a převzatou půdu použít $\mathrm{k}$,účelům všeobecně prospěšným“", nebo ji přidělit fyzickým či právnickým osobám vymezeným v tzv. přídělovém zákoně, ${ }^{9}$ přičemž původnímu majiteli byla vyplacena „náhrada“ (přejímací cena) dle tzv. zákona náhradového. Vzhledem k niternému vztahu $\mathrm{k}$ půdě a hospodářským výnosům měly státní zásahy do majetkové držby pro jednotlivé rody a jejich knihovny v mnoha ohledech osudné následky. Samostatnou kapitolou pak byl pozemkový či jiný hmotný majetek rakousko-uherských státních domén, korunních statků či soukromého vlastnictví Habsbursko-Lotrinské císařské dynastie, jenž na základě Saint-Germainské mírové smlouvy připadl Československu, kde se stal doménou ministerstva zemědělství (dále jen často „MZe“), popř. na jeho správě participovaly také další státní instituce, zejména ministerstvo školství a národní osvěty (dále je často „MŠNO“).

Pokud zámecké knihovny či jejich části nepodlehly živelním pohromám, nedošlo k jejich vývozu do zahraničí, rozkradení nebo jinému znehodnocení, pak se do rukou státu dostaly bud' coby konfiskovaný majetek členů někdejší vládnoucí dynastie, nebo v souvislosti s prováděním pozemkové reformy. Jinak zůstaly v soukromých rukou majitelů zámeckého sídla toho kterého rodu.

Zabíráním rozsáhlých pozemkových statků bylo nutné postarat se také o kulturní hodnoty, jež kromě hmotných památek spadajících do kompetence zemských památkových úřadů MŠNO, představovaly taktéž archivy a hospodářské registratury velkostatků. Zatímco pro jejich zajištění ze strany státních institucí byl přijat alespoň nějaký legislativní rámec v podobě $\S 2$, bodu 9 zák. č. $118 / 1920$ Sb. z. a n. ${ }^{10}$ a $\S 33$ „náhradového“ zákona ${ }^{11}$, situace starobylých zámeckých knihoven zůstala z hlediska jejich zajištění a využití ve veřjejném zájmu nedostatečná. „Naši knihovníci, zdá se, bud’ si neuvédomili své povinnosti, neb nedovedli včas uplatniti svého vlivu v zákonodárných sborech, aby prí reformě pozemkové bylo pamatováno též nejen snad na záchranu, nýbrž i na zveřejnění neb aspoň zpř́stupnění zámeckých knihoven. [...] Uvědomíme-li si, kolik set zámků máme v našem státě, a zjistíme-li si, že na každý jen pátý neb desátý zámek připadne zámecká knihovna o několika tisících svazků, poznáme,

\footnotetext{
${ }^{2}$ OOSTERHUIS 1926, s. 289.

${ }^{3}$ LIFKA 1933, s. 129.

${ }^{4}$ HOMOLOVÁ-JELÍNKOVÁ 2020, s. 7.

${ }^{5}$ Zák. č. 61/1918 Sb. z. a n.

${ }^{6}$ PEKAR̆ 1923.

${ }^{7}$ Činnost SPÚ probíhala od 15. 10. 1919 do 1. 5. 1935, kdy byl zrušen vládním nařízením z ledna 1935 a jeho agenda přešla do IX. odboru ministerstva zemědělství. Podrobně viz JANDEROVÁ - HAAS 1966, s. 1-4.

${ }^{8}$ Dle $\S 11$ zák. č. 215/1919 Sb. z. a n.

${ }^{9}$ Zák. č. $81 / 1920$ Sb. z. a n.

${ }^{10}$ „, K udržováni majetku v dobrém stavu náleži zejména: bezpečné uložení a náležité opatrování archivů, registratur, př́ručních spisoven a správních knihoven, vyjímajic věci čistě rodinné. "Srov. § 2, bod 9 zák. č. 118/1920 Sb. z. a n.

${ }^{11}$ „Převezme-li pozemkový úřad celé statky, at’ po částech nebo najednou, prevezme zároven jako podstatnou část statku bez zvláštní úplaty archivy a registratury patrimoniálni a hospodárské správy. Písemnosti rodinné zůstanou v držení dosavadních vlastníkủ, podrobi-li se podminkám stanoveným pozemkovým úradem v dohodě s ministerstvem školství a národni osvěty, pokud jde o umožnění studia jednotlivých listin nebo knih majicich význam všeobecně historický. "Srov. § 33 zák. č. 329/1920 Sb. z. a n.
} 
jaké kulturni hodnoty skrývaji zámecké knihovny a jaký mohly by míti pro nás význam, kdyby byly povinně učiněny př́stupny aspon̆ pracovníki̊m védeckým, když ne celému národu. "12

Po kompetenčních sporech mezi MŠNO a MZe souvisejících jednak $\mathrm{s}$ novou organizací archivnictví $\mathrm{v}$ Československu, jednak $\mathrm{s}$ nakládáním $\mathrm{s}$ archiváliemi na zabraném pozemkovém majetku, ${ }^{13}$ byl nakonec především díky zásluze Adolfa Ludvíka Krejčíka (1877-1958) ${ }^{14}$ zřízen v rámci 1. oddělení I. odboru ministerstva zemědělství - Československý státní archiv zemědělský (ČSAZ), ${ }^{15}$ jenž se do budoucna stal výkonným orgánem k zabezpečení a inventarizaci archiválií a hospodářských registratur na zabraném velkém majetku pozemkovém, jenž byl v gesci ministerstva zemědělství spravován Generálním ředitelstvím státních lesů a statků. ČSAZ tak k nelibosti některých archivářů či MŠNO zaplnil mezeru, kterou vzhledem k náročnosti rozjíždějící se pozemkové reformy nedokázaly vyplnit archivní inspektoři či okresní konzervátoři písemných památek a svoji činnost prováděl nejen $\mathrm{v}$ př́ípadě zabraných statků, ale i na dožádání SPÚ či po vzájemných dohodách se soukromými vlastníky.

První roky úřadování ČSAZ byly vyplněny hektickou činností související jednak se zařizováním úřadu, jednak s úkoly vyplývajícími z odborného pracovního zaměření instituce, tj. zejména vytřídění, převzetí a zabezpečení dokumentace získané archivní a spisovou rozlukou s Rakouskem (1920 až 1924, posléze i s dalšími nástupnickými státy) a paralelní zajištění dokumentace v rámci probíhajících inspekcí na velkostatcích v tuzemsku. Ty prováděli kromě samotného ředitele Krejčíka také další zaměstnanci, renomovaní archiváři a historici, PhDr. Václav Černý (1894-1962), PhDr. Emanuel Janoušek (1897-1970) či Karel Jeřábek (1899-1950). Při služebních cestách byl jejich primární zájem soustředěn zejména na archivní a spisový materiál včetně správních knihoven toho kterého statku, na řadě míst však taktéž prohlédli (popřr. zinventarizovali) také zámecké knihovny. Na základě Krejčíkových zpráv a odhadů o počtech svazků můžeme říci, že se tak stalo např. v Brandýse nad Labem, Bruntále (20 114 svazků), Bouzově (asi 300 až 400), Bystrém u Poličky (600), Chlumu u Třeboně (2 000), Nových Hradech, Ivanovicích na Hané (2 000), Konopišti (6 000), Kravařích (5 000), Kuksu, Modré, Ostrově u Karlových Varů (7 000), Poděbradech, Sovinci (3 000 až 4 000), Topolčiankách (11 877), Zákupech (700) a Židlochovicích. ${ }^{16}$

V př́ipadě zámeckých knihoven přejatých do vlastnictví státu došlo $\mathrm{v}$ řadě případů $\mathrm{k}$ jejich využití pro veřejné účely - např. zámecká knihovna z Brandýsa nad Labem přešla do vlastnictví Národního muzea, zámek v Kravařích byl i s knihovnou zakoupen pro Státní hospodářskou a hospodyňskou školu, nejcennější bibliotéky však zůstaly v soukromých rukou a jejich ochrana ze strany státu byla nedostatečná v podstatě až do konce první republiky, jak si o tom posteskl A. L. Krejčík v druhé polovině třicátých let: „, Budu vždy litovati, že nebylo obdobné ustanoveni jako o archivech a registraturách hospodářské správy pojato do tohoto zákona [,náhradového“] též ustanovení o oněch rodinných archivech majitelů zabraných statků, jež chovají bohaté archiválie pưvodu státního, jež do těchto archivio uložili šlechtičtí funkcionáři státní, někdejši ministři, vyslanci, vysocí úředníci apod., a že také podobně nebylo pamatováno na cenné staré knihovny zámecké, jak jsem o to usiloval. Stále slibovaný zákon o ochraně památek písemných měl by toto ,přehlédnuti" v zájmu věci napraviti. "17

Stejně jako jinde v Evropě tak i v ČSR se v meziválečném období odehrály rozsáhlé prodeje šlechtických knižních sbírek, jež se přední znalec zkoumané problematiky

\footnotetext{
${ }^{12}$ KREJČÍK 1922, s. 9.

${ }^{13}$ K tomu podrobně viz JANOUŠEK 1968, s. 147-180.

${ }^{14} \mathrm{PhDr}$. Adolf Ludvík Krejčík se narodil dne 14. 6. 1877 v Dobrovici na Mladoboleslavsku jako jedenácté dítě Josefu Krejčíkovi a Marii, roz. Heszové. Vysokoškolská studia v oborech historie a filologie vykonal na Univerzitě Karlo-Ferdinandově v Praze, kde byli jeho přednášejícími např. T. G. Masaryk, J. Goll, Č. Zíbrt ad. V roce 1897 byl Gollem doporučen pro studium na Institut für österreichische Geschichtsforschung (Ústav pro rakouský dějezpyt ve Vídni), jehož absolventi splňovali odborné předpoklady pro práci archivářů, muzejníků či školených knihovníků. Vídeňská studia úspěšně dokončil v roce 1899 a následující léta strávil na stipendijních pobytech v Německu a Itálii. Na první pracovní místo Krejčík nastoupil ve schwarzenberském archivu v Třeboni, kde započala jeho odborná práce o patrimoniální správě a zájem o historii zemědělství. V letech 1909 až 1919 pak působil v Moravském zemském archivu v Brně, v němž se zabýval problematikou moravských klášterů. V červnu 1914 obhájil na pražské univerzitě disertační práci na téma Prolegomena $k$ vydání T. J. Pešinova díla „,Mars Moravicus “ a získal titul doktora filozofie. V období první republiky působil do r. 1937 jako ředitel ČSZA, také zastával funkce ředitele Ústřední slovanské knihovny a čitárny Československé akademie zemědělské. Taktéž figuroval v řadě předních knihovních či archivních spolků a na počátku okupace pomáhal coby penzista vypracovávat rodopisné studie k prokazování árijského původu. KUPROVÁ 2014, s. 11-14; ZEIBRDLICH 1931, s. 139.

15 Úkolem ČSAZ bylo v obecné rovině pečovat o zemědělské archivnictví, dějiny zemědělství (např. výroby, průmyslu), zemědělského obyvatelstva, sloužit účelům vědeckým a výchovným (např. bádání o dějinách zemědělství, šíření osvěty pro ochranu starých písemných zemědělských památek, získávání pramenů a vytváření bibliografí $\mathrm{k}$ zemědělským dějinám) včetně plnění dožádání veřejné správy (zejm. ministerstva zemědělství). Do správy ČSAZ spadaly: veškeré spisy registratur dř́ivějších ministerstev orby c. a k. rakouského a kr. uherského, pokud dle mírových smluv prripadly ČSR a nestaly se součástí spisovny ministerstva zemědělství, dále veškeré archivy a hospodářské registratury panství a státních statkủ, včetně statků nadačních spadajících pod ministerstvo zemědělství, zájmových korporací či jednotlivců, pokud je ČSAZ darovali či dali do úschovy. Z literatury zabývající se ČSAZ viz zejm. KREJČÍK 1920; KREJČÍK 1921; KREJČÍK 1924; KREJČIK 1927; KREJČÍK 1928; KREJČÍK 1929; KREJČÍK 1937; JANOUŠEK 1926; JANOUŠEK 1931; JANOUŠEK 1933; JANOUŠEK 1934; JANOUŠEK 1934a; JANOUŠEK 1968; ČERNÝ 1952.

${ }^{16}$ KREJČÍK 1922, s. 9

${ }^{17}$ KREJČÍK 1937, s. 7.
} 


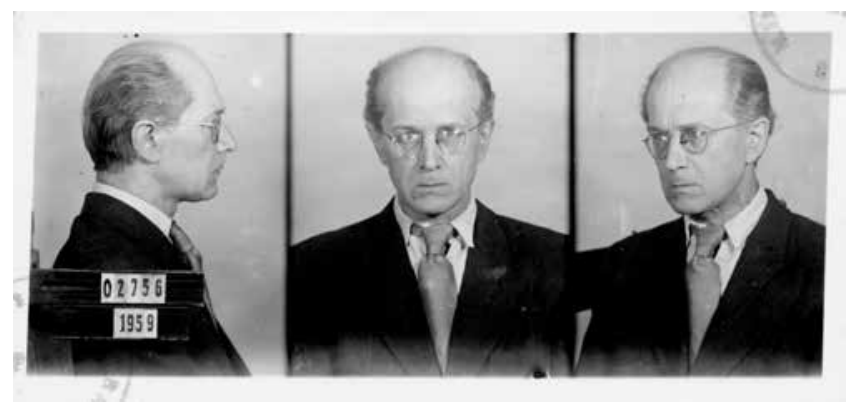

Obr. 1. Bohumír Lifka ve vyšetřovací vazbě StB. Zdroj: ABS, sbírka Správa vyšetřování StB - vyšetřovací spisy (V), arch. č. V-3571 MV, osobní vyšetřovací spis B. Lifka

Bohumír Lifka ${ }^{18}$ nebál srovnávat s obrovskými ztrátami souvisejícími s rušením klášterů za Josefa II.

Mezi hlavní příčiny uvolňování zámeckých knihoven pro trh, umocněnými zrušením fideikomisů a procesy spjatými s pozemkovou reformou, je nutné počítat ztrátu dřívější společenské prestiže vrchnostenských majitelů, obecné zadlužení, daňové zatížení spojené s nemožností dosáhnout dřivějších hospodářských výnosů, náklady na reprezentaci a správu sídel či ztrátu zájmu mladších generací na dalších osudech knižních sbírek jejich předků. ${ }^{19}$, ,I když udržovací náklady na bibliotheku byly mnohdy nepatrné, ba žádné mistnost knihovny byla zpravidla po celý rok zavrena a ukazována jen hostům, bibliothekár býval naposledy jen čestný titul a prrídavek funkce zámeckého vychovatele nebo kaplana - nejdřiv knihovna se stala přitěží, když došlo k prodeji některého filiálního sídla, z něhož vzaty byly na milost $k$ prevozu a opětné instalaci v zbylém nebo hlavním sídle obyčejně jen věci obecněji chápatelné a ocenitelné hodnoty: nábytek, obrazy, grafika. Stalo-li se, že se zželelo majetniku prodeje celé knihovny, vybral si jen věci, jež hověly nynějšímu vkusu, zálibě a zaměstnáni: biografie a memoiry (psychologický moment, pripomínání si bývalé slávy, shližení se v staré citovosti), genealogie, knihy o honbě a lovu, ilustrované knihy o př́rodě, cestopisy, sport, militaria, umění, obrazová alba. " ${ }^{20} \mathrm{Jen}$ pro období let 1923 až 1933 odhadl Lifka, že formou přímého prodeje či prostřednictvím aukcí došlo $\mathrm{k}$ přesunu více jak dvou set tisíc „starých a vzácných“ knižních titulů do rukou nových majitelů. Ti zakoupené celky uložili do svých soukromých sbírek, nebo je dále „rozdrobili““ a rozprodali. ${ }^{21}$

I přes střídající se ekonomické propady a hospodářské krize se od poloviny 20. let staly v ČSR módními a oblíbenými rozličné aukční prodeje, ${ }^{22} \mathrm{v}$ nichž byly nabízeny také části či celé sbírky uměleckých předmětů a zámeckých knihoven, jejichž majitelé se snažili zvrátit svoji ,zápornou

\footnotetext{
${ }^{18}$ PhDr. Bohumír Jan Lifka se narodil dne 24. 3. 1900 v Radomyšli na Strakonicku do rodiny obchodníka Bohumíra Lifky (nar. 1864) a jeho manželky Anny Rozárie Lifkové, roz. Fialové (nar. 1871). O čtyři roky později přišel na svět také jeho bratr Karel Lifka. Již od mladšího školního věku se stala Lifkovou zálibou četba, jež ho provázela po celý život. Během studií na Jirsíkově gymnáziu v Českých Budějovicích začal vypomáhat ve veřejné české knihovně provozované spolkem Národní jednoty pošumavské, což mělo zásadní vliv na jeho budoucí profesní dráhu. Po maturitě studoval Státní knihovnickou školu a Filozofickou fakultu Univerzity Karlovy (1919-1923), kde byl po složení rigorózních zkoušek z „filozofie“ a „dějin moderních literatur“, společně s obhájením disertační práce na téma Josef Dastich. Přispěvek k dějinám českého herbartismu, promován doktorem filozofie dne 5. 12. 1923. V průběhu vysokoškolských studií byl Lifka přiveden PhDr. Jaromírem Malým, knihovníkem právě zakládané knihovny Národního shromáždění, do „Spolku sběratelů a přátel exlibris a jiné užitkové literatury“, a také se dostal do kruhů osob kolem spisovatele a filozofa Rudolfa Iny Malého a novináře, spisovatele a literárního kritika Františka Xavera Šaldy. Od roku 1923 do první poloviny 30. let působil Lifka postupně jako knihovník Národního shromáždění, Akademického domu či Veřejné a univerzitní knihovny v Praze. Dne 20. 9. 1930 se oženil s Marií Baborovou (nar. 2. 5. 1908) a z manželství vzešly dvě děti - syn Michael Lifka (nar. 28. 10. 1932), jenž později působil jako knihovník v Národní knihovně, a dcera Helena Lifková (nar. 26. 5. 1942). V letech 1934 až 1959 byl Bohumír Lifka správcem knihovny Náprstkova muzea v Praze. Dále působil jako redaktor (1925-1927) a tajemník redakce (1927-1933) Masarykova slovníku naučného či jako redaktor Erbovni knižky a Marginalii. V roce 1937 se stal členem charitativního Rádu rytírư svatého Lazara Jeruzalémského („lazariáni“) a taktéž byl aktivní v Řádu Maltézských rytiřů. Mezi hlavní Lifkovy badatelské zájmy patřilo zkoumání historie zámeckých knihoven, odborně se zabýval osobností Františka Xavera Šaldy, dějinami filozofie či minulostí Řádu Maltézských rytiřů. V roce 1945 se stal členem Československé strany lidové a zároveň byly před Čestným soudem Svazu českých knihovníků řešeny jeho údajné prohřešky z minulých let. Za publikační činnost v periodicích „Tak“ a „Pruty“ před okupací mu bylo pro odbornou knihovnickou činnost uloženo silentium do 31.12 .1947 , naproti tomu obvinění útočící na jeho „národní a státní spolehlivost“ bylo vyvráceno. V roce 1947 bylo B. Lifkovi ministrem školství a národní osvěty uděleno ocenění „,vzorný pracovník ministerstva školstvi“. V 50. letech se Lifka nadále angažoval v již zakázaných lazariánech, což se mu nakonec stalo osudným. Dne 14. 2. 1959 došlo k jeho zatčení Státní bezpečnosti (StB). Ve dnech 15.-16. 7. 1959 stanul společně s dalšími osobami označenými jako „JUDr. Jiří Suchánek a spol.“ před senátem Krajského soudu v Praze, jímž byl odsouzen na sedm let vězení společně se ztrátou čestných práv občanských a propadnutím celého majetku. V odůvodnění rozsudku byl Lifka označen za „obdivovatele katolické šlechty a duchovenstva“, což ho přivedlo mezi lazariány a maltézské rytíře, kteří dle obvyklých floskulí „sledovali zvrat lidově demokratického státního zrrízení“. V souvislosti s činností Řádu Maltézských rytiřů uškodili v té době již bývalému řediteli Náprstkova muzea odesílané dopisy do zahraničí vztahující se k činnosti a stavu řádu či zprostředkované kontakty s uprchlým Karlem Schwarzenbergem. V rámci aktivit s lazariány měl zase Lifka na společných schůzkách údajně vyzývat ostatní členy k aktivnímu odporu vůči komunismu. Nakonec byl charakterizován jako „,zavilý a záludný neprrítel lidově demokratického státního zř́izení s mizivou možností nápravy a převýchovy“. Zbývalo již jen obrátit se k soudu vyšší instance. Nejvyšší soud v Praze rozsudkem ze dne 17. 9. 1959 však odvolání zamítl. Naštěstí přišel rok 1960 a s ním spojená plošná amnestie, která se týkala taktéž Bohumíra Lifky, jemuž byl prominut zbytek trestu odnětí svobody s podmínkou na deset let a v rámci amnestie v roce $1965 \mathrm{mu}$ byl prominut i zbytek „zkušební doby“. Koncem 60. let byl Lifka nejprve zbaven absurdních obvinění a soudně rehabilitován před Zvláštním senátem pražského krajského soudu, proti jehož výroku se však odvolal generální prokurátor a změněné politické poměry po okupaci vojsky Varšavské smlouvy zapř́íinily zrušení tohoto rozhodnutí. Soudní anabáze se táhla až do roku 1976, kdy bylo v obnoveném řízení Lifkovo stíhání zastaveno. Srov. SOA Třeboň, Sbírka matrik, matrika narozených 1900-1910, záznam č. 35, fol. 2; AUK, Matrika doktorů UK, inv. č. 5, Matrika doktorů Univerzity Karlovy V., s. 2280; ABS, sbírka Správa vyšetřování StB - vyšetřovací spisy (V), arch. č. V-3571 MV, osobní vyšetřovací spis B. Lifka, protokol B. Lifky na Správě vyšetřování MV v Praze ze dne 15. 2. 1959, s. 33-34; Tamtéž, skupinový spis - trestní oznámení, žaloba, soudní
} protokoly a rozsudky vztahující se k B. Lifkovi; KNIHOVNA 1945b, s. 71. TOMEŠ 1999, s. 274. KNEIDL 1997.

${ }^{19}$ LIFKA 1933, s. 130-131.

${ }^{20}$ Tamtéž, s. 131 .

${ }^{21}$ Tamtéž, s. 130-131.

${ }^{22}$ Historie knižních aukcí měla v českých zemích tradici z přelomu 18. a 19. století. První z nich uskutečnil majitel čítárny časopisů a půjčovny knih Ondřej Gerle v pražské Celetné ulici dne 22. 3. 1784 a jejich úspěch trval až do roku 1804. V průběhu 19. století pořádala knižní aukce pražská Univerzitní knihovna či nakladatel a knihkupec Adolf Kuranda. Srov. HÁLA 1948, s. 35. 
platební bilanci“. Vzhledem k unikátnosti a ceně se tuzemské nabídky staly atraktivní také pro zahraniční sběratele a knihkupce, kteří zde at' již přímo či v aukčních síních nakupovali za nízké ceny. Bohužel v řadě př́padů selhaly státní instituce, které mohly intervencemi či investicemi zabránit únikům kulturního bohatství do zahraničí. ,, Ministerstvo financí však zdaleka neplní vzhledem $k$ možnostem vzácných investic na staletí svou čestnou povinnost, zejména pokud běži o nebohemikální rarissima, která jsou šmahem vyvážena za hranice. Touto neblahou politikou se děje, že se Čechy stávaji již několik let rejdištěm cizich antikvář̀i, kteři se nespokojuji nabídkami majitelư, nýbrž v mnoha zjištěných prípadech nutí a premlouvaji bývalé šlechtice k prodeji jednotlivých knih a celých knihoven. Velké množství zámků se zbavuje knihoven a tento stav trvá. Noví nabyvatelé se jen zřídka těši z nalezené knihovny; obyčejně ji zakrátko prodají. Mecenáši veřejných sbirek pritom nevznikají. Noví bibliofilové mezi zámeckými pány se rodí velmi sporadicky [...]. "23

Mezi nejvýznamnějšími nakladatelstvími a osobnostmi zabývajícími se aukčním prodejem knižní produkce za první republiky je možné zmínit „Orbis“ a „Naši knihu“, dále pak pražské knihkupce a antikváře - Karla Finka, Oldřicha Pyšvejce (obchod v Jindřišské ulici) a jeho bývalého žáka a zaměstnance, obnovitele pravidelných knižních aukcí v Čechách, Karla Zinka, ${ }^{24}$ jehož podnik sídlil v Ječné ulici. Zinkovy dražby v pražském hotelu Beránek na Tylově náměstí se staly proslulými, ${ }^{25}$ stejně jako aukční katalogy, na jejichž sestavování se $\mathrm{v}$ mnoha př́ípadech podílel taktéž B. Lifka. Od první Zinkovy aukce uspořádané dne 5. 10. 1925 proběhlo do roku 1949 celkem šedesát pět dražeb „vzorně a védecky pripravených, jimž dovedl dodat pevný rád a sloh. Byly to zejména aukce ucelených šlechtických knihoven, knihoven vydavatele Moderní revue Arnošta Procházky a řady jiných sběratelü “. ${ }^{26}$

Z dalších aukčních síní či osobností zabývajících se nejenom knižními dražbami je možné zmínit ještě populární pražské aukce Zdeňka Jeřábka ve Spálené ulici, dále Ladislava Ryšavého, jenž je od roku 1927 provozoval v Jeruzalémské ulici, kde původně pořádal od roku 1921 dražby Státní zástavní úřad. Nezapomenout bychom neměli ani na aukce Stanislava Budila v parlamentní budově na Malé Straně, uměleckého salonu Jindřicha Slatnera (zal. r. 1926) a akademického malíŕe Moritze Müllera na Národní trrídě, uměleckého knihaře a nakladatele Ludvíka Bradáče nebo v menším měřítku na dražby spisovatele a bibliofila Václava Augusta (pseudonym Jan Maria August) či Syndikátu výtvarných umělců. Vyhlášenými se v letech 1926 až 1931 staly také nabídky aukční síně Sdružení pražských starožitníků „Maison antique“ se sídlem na Masarykově nábřeží v Praze pod vedením Karla Rosenkranze, Karla Chaury a Antonína Nečase, které se zaměřovaly na rozprodej šlechtických sbírek a zámeckých deposit. Za jednu z jejích nejvýznamnějších aukcí můžeme považovat prodej inventáře průhonického zámku (dnes Národní kulturní památka a součást UNESCO) ve dnech 8. až 9. října 1928, k němuž dalo svolení ministerstvo zemědělství, jemuž zámek kvůli ekonomickým obtížím prodal hrabě Arnošt Emanuel Silva-Tarouca (1860-1936) $\mathrm{v}$ roce $1927 .^{27}$

Z hlediska veřejného zájmu bylo lepší, uskutečnil-li se prodej zámeckých knižních sbírek ve prospěch československého státu, popř. některé z veřejných knihovních, vědeckých či kulturních institucí (at' již přímo či prostřednictvím dražby), jejichž zástupci sledovali aukční katalogy a nejednou se zúčastnili i samotných licitací. Státem byly ve dvacátých a třicátých letech získány koupí či jinou formou (mimo vyvlastnění) např. knihovna Kinských, kterou měla pronajatou v letech 1921 až 1936 Státní knihovnická škola; Josefa Marii Baernreithera z Mlýnců (1845-1925) pro Knihovnu Národního shromáždění v roce 1926; bohatá a rozmanitá palácová knihovna pražské lobkovické sekundogenitury o 34073 svazcích, jejíž sbírky i se skvostem v podobě Velislavovy bible (vytvořena $\mathrm{v}$ letech 1325-1349) přešly jako celek do Veřejné a univerzitní knihovny ${ }^{28}$ (dále jen často VUK) v roce 1928; křivoklátská knihovna Fürstenberků o 24423 titulech v roce 1931; knihovna baronů Sina a jejich dědiců princů Hohenlohe-Schillingfürst a Ipsilanti, jež přešla pod Hellichovo muzeum Poděbradska; knihovna Františka

\footnotetext{
${ }^{23}$ LIFKA 1934, s. 17.

${ }^{24}$ Karel Zink se narodil dne 27. 4. 1889 na Královských Vinohradech. V letech 1907 až 1910 se vyučil knihkupcem u Oldřicha Pyšvejce, v jehož firmě pracoval do roku 1918. V letech 1919 až 1923 řídil antikvariát Zemědělského knihkupectví a nakladatelství A. Neuberta. Vlastní závod otevřel dne 5. 11. 1923 a o dva roky později začal s pořádáním knižních aukcí, čímž obnovil tradice pražských knižních dražeb z 18. a 19. století. V roce 1942 byla Zinkovi odňata licence pro jeho členství v zednářské lóži. Po okupaci se v letech 1945 až 1946 stal národním správcem několika bývalých pražských německých antikvariátů a společně s Františkou Švábovou (1897-1966) znovu otevřel knihkupectví a antikvariát se sídlem v pražské Mostecké ulici, přičemž v roce 1946 obnovil v Malostranské besedě také knižní aukce. V letech 1949 až 1955 pracoval v zestátněném antikvariátu (Orbis, n. p., od roku 1953 Kniha, n. p.), kde uspořádal dalších deset knižních dražeb. Po celý život se významně angažoval ve Spolku českých bibliofilů a působil také ve Spolku sběratelů a přátel exlibris. Zemřel dne 13. 12. 1975 ve věku osmdesáti pěti let. Srov. Internetový portál Slovnik českých nakladatelství 1849-1949, heslo Karel Zink. Dostupné z: https://www.slovnik-nakladatelstvi.cz/nakladatelstvi/karel-zink.html [cit. 20.6. 2020].

${ }^{25}$ XV. aukce byla pořádána v Brně ve dnech 9. až 10. 6. 1928 a pro moravskou metropoli se stala kulturní senzací.

${ }^{26}$ TOMAN 1969, s. 5.

${ }^{27}$ TRIBUNA 1928, s. 5; TRIBUNA 1928a, s. 5; Internetový portál ART+: vše o trhu s uměním - přehled historie pražských aukcí $1912-1939$. Dostupné z: https://www.artplus.cz/cs/aukcni-zpravodajstvi/1/z-historie-prazskych-aukci [cit. 15. 3. 2020]; Internetový portál Akademie věd České republiky (AV ČR, v. v. i.) - Botanický ústav AV ČR, v. v. i. - zámek Průhonice. Dostupné z: http://www.pruhonickypark.cz/cs/zamek/ historie-zamku/ [cit. 20. 6. 2020].

${ }^{28}$ NK ČR v průběhu své historie změnila několikrát svůj status i název. Svou novodobou historii započala v roce 1777 jako Veřejná c. k. universitní knihovna. Po vzniku samostatného Československa změnila název na Veřejná a universitní knihovna. V roce 1919 byl ke knihovně přičleněn nově vzniklý Československý ústav bibliografický, jeho činnost převzalo v roce 1925 nově zřízené konzervační oddělení nazvané Národní knihovna. V roce 1935 byla přejmenována na Národní a universitní knihovnu a s výjimkou protektorátního období byla pod tímto názvem známá až do roku 1958, kdy změnila název na Státní knihovnu Československé republiky (dále od roku 1960 jako Státní knihovna Československé socialistické republiky, od r. 1969 v důsledku politických změn České socialistické republiky).
} 
a Anny Lützowových, která byla odkázána Národnímu muzeu a Ústřední knihovně města Prahy. ${ }^{29}$ Naopak v přímých prodejích soukromým osobám či $\mathrm{v}$ aukčních síních se rozptýlila řada unikátních a cenných šlechtických knihoven, jejichž majitelé se ocitli ve finanční nouzi, jako např. Pálffyové, Dietrichsteinové či Thun-Hohensteinové.

První poválečná tuzemská knižní aukce většího formátu se týkala knihovních sbírek obsažených v pozůstalosti uherského hraběte Jana (Jánose) Františka Pálffyho z Erdödu (1829-1908) nacházející se v bratislavském paláci a slovenských zámcích v Král'ové, Pezinku a Bojnici. ${ }^{30}$ Uskutečnila se ve dnech 8 . až 10 . března 1926 v Praze a za nejvzácnější vydražený titul s vyvolávací cenou 15000 Kč, který po zaplacení vydražené částky 56000 Kč putoval do ciziny, bylo považováno dílo Tomáše Kempenského (Thomas Haemmerken, asi 1380-1471) „De Imitatione Christi“ („O následování Krista“) vytištěné v Augspurku kolem roku $1470 .{ }^{31}$

Nejvzácnější díla moravské dietrichsteinské zámecké knihovny z mikulovského zámku, nepočítáme-li vývoz padesáti tří inkunábulí v roce 1927, se „rozplynula“ ve švýcarských a rakouských aukčních síních v letech 1933 až $1934 .^{32}$ Dražby uskutečněné pod taktovkou firmy H. Gilhofer \& H. Ranschburg v Luzernu ve dnech 21. až 22. listopadu 1933 a 25. až 26. června 1934 a ve Vídni ve dnech 27. února až 1. března 1934, se staly evropskou senzací. ${ }^{33} \mathrm{~V}$ první luzernské dražbě byla celková hodnota 795 vybraných knižních jednotek a konvolutů z více jak třiceti tisíci svazkové knihovny odhadnuta na 266150 švýcarských franků, což v té době činilo asi 1730000 Kč a největší část vydražil londýnský antikvariát Goldschmidt. ${ }^{34}$ Nejpočetněji byly zastoupena díla z př́rodních věd, medicíny a inkunábule. ${ }^{35}$ Přestože bylo před aukcí Státním památkovým úřradem zabráněno vyvézt unikátní prvotisky zahraniční provenience a československým státem byla odkoupena sbírka bohemikálních rukopisů, $\mathrm{k}$ jejichž výběru byli do mikulovského zámku vysláni ředitel Veřejné a univerzitní knihovny PhDr. Jan Emler (1877-1951) a ředitel Knihovny Národního muzea PhDr. Josef Volf (1878-1937), dostalo se na trricet vzácných bohemik do aukční síně a zpátky do ČSR jich šlo pouze devět. Janu Emlerovi přítomnému aukční licitaci se podařilo „ukořistit“" latinsky psanou Alexandreidu z poloviny 15 . století za $5057 \mathrm{Kč},{ }^{36}$ zbytek putoval do soukromých rukou Otokara Kruliše-Randy (1890-1958) a tvořily ho tři rukopisy předhusitské éry z rokycanského augustiniánského kláštera včetně pergamenového rukopisu sv. Remigia z Remeše z 11. století a dalších pět tisků, mezi nimiž figurovala Bible kralická $\mathrm{z}$ roku $1596 .{ }^{37}$ Celkový finanční profit z aukce byl vcelku dobrý, avšak výsledná částka dražených jednotek málokdy dosáhla či přesáhla odhadní ceny. ${ }^{38}$ Při druhé aukci ve švýcarském městě na březích Vierwaldstätterského jezera bylo draženo 536 položek společně s moderním uměním a luxusními tisky. Největší zastoupení skýtaly tituly francouzské literatury či díla věnující se prrírodním vědám. Na vídeňské aukci pak byly nabízeny rukopisy a tisky, z nichž se podařilo VUK prostřednictvím tuzemské antikvářské firmy zakoupit dva exempláře pražských kaligrafických sborníků předloh písma ABC-Buch Petra Franzy a Küsela Berky z počátku 19. století. ${ }^{39}$ Celkem se knihovně podařilo z Dietrichsteinské bibliotéky odkoupit 117 rukopisů a 208 prvotisků, které byly uloženy v Moravském zemském archivu a v roce 1944 přešly do dnešní Moravské zemské knihovny v Brně. Další část rukopisů se stala v 50. a 60. letech součástí depozit Knihovny Národního muzea a pocházely ze sbírek výše zmíněného O. Kruliše-Randy. ${ }^{40}$

Zatímco mikulovská knihovna byla rozprodána $\mathrm{v}$ zahraničí, naše patrně nejvýznamnější a nejbohatší soukromá bibliotéka - děčínská zámecká knihovna Thun-Hohensteinů

\footnotetext{
${ }^{29}$ LIFKA 1934, s. 17-18; KNEIDL 1956, s. 169

${ }^{30}$ Pokud pomineme vídeňské dražby pálffyovských sbírek z počátku 20. let 20. století, pak tuzemské knižní aukci předcházely dva rozprodeje uměleckých předmětů shromážděných především zmíněným Jánosem Pálffym. Uspořádány byly Východoslovenským museem v Košicích v Piešt’anech ve dnech 30. 6. až 1. 7. 1924 a v Praze ve dnech 2. až 3. 12. 1924. Mezi vzácnými gobelíny, obrazy, vídeňským porcelánem, bronzovými a mramorovými plastikami byly nabízeny taktéž knižní tituly, jejichž prodaný počet odhadl Bohumír Lifka na 2000 kusů. Srov. LIFKA 1933, s. 130; TOMAN 1924, s. 174; LIDOVÉ NOVINY 1924, s. 7.

${ }^{31}$ ČASOPIS ČESKOSLOVENSKÝCH KNIHOVNÍKU゚ 1926, s. 51-52; LIDOVÉ NOVINY 1926, s. 7.

${ }^{32}$ PETR 2003, s. 122.

${ }^{33}$ K průběhu dražeb srov. KAUCKÁ 2015, s. 28-33.

${ }^{34}$ LIFKA 1933a; s. 9. KAUCKÁ 2015, s. 29.

${ }^{35}$ KAUCKÁ 2015, s. 35.

36 Tamtéž, s. 45.

${ }^{37}$ GRUND 1933, s. 9; LIFKA 1934a, s. 18-19.

${ }^{38}$ Knihovník Antonín Grund, jenž na aukci zastupoval zájmy O. Kruliše-Randy, o tom referoval v Lidových novinách: „,Prodalo se kromě několika svazkư vše, ač pravidelně pod odhadní cenou, jež jen v málo př́padech byla podstatněji překročena. Pergamenový némecký pasionál z polovice 14. století s tužovými kresbami na deskách pravděpodobně rakouského původu prodán za 1850 švýc. Frs. (odhadní cena 750 ), Amisův „Strikker“, středohornoněmecký rukopis na pergamenu s jemnými iniciálovými kresbami, za 4600 (1 800), Terentiovy komedie v opisu spolutvi̊rce mikulovské knihovny humanisty Hieronyma Münera z let 1460-1473 za 610 (360), rukopis „, Schsenspiegeln“ ve třech svazcích z druhé polovice 15. stol. za 900 (800). Jinak rukopisy německé i soubor řeckých rukopisü, mezi nimi vzácně vypracované kusy z 10. až 12. století prodávaly se hluboko pod cenou: homilie Řehoře z Naziance za 2500 (odhad 6 000), Johannes Damascenus za 1500 (4 000), výklad na osm knih Starého zákona za 2600 (6 000), původní rukopis ulmského dominikána Felixe Fabri „Descriptio Theutonie et Nationis Suevie et civitas Ulme“ z konce 15. stol. za pouhých 250 (1 500). Zklamala vrcholná čisla aukce, raný opis 10. století kapitularii Karla Velikého v redakci Ansagisově, jež prodána za 4200 (odhad 10 000), nejdražši kus aukce, řecký evangeliář z počátku 12. stoletís pèti celostránkovými miniaturami a ve skvělé byzantské vazbě, oceněný na 15 000, prodán za 6500 [...]. "Srov. GRUND 1933, s. 9.

${ }^{39}$ KAUCKÁ 2015, s. 32.

${ }^{40}$ PETR 2003, s. 123 a 126.
} 
se dočkala několika aukcí v Praze pořádaných Karlem Zinkem a Oldřichem Pyšvejcem v letech 1933 až 1934. ${ }^{41}$ Prodeji knihovny, jež mohla mít údajně až kolem devadesáti tisíc svazků, ${ }^{42}$ předcházely ekonomické problémy Františka Antonína Thun-Hohensteina (1890-1973). Ten se snažil svoji svízelnou ekonomickou situaci vyřešit odprodejem zámeckého komplexu a přesunem rodiny do zámečku v Jílovém u Děčína, kam se dala rozsáhlá knihovna stěží převézt. Po vzájemných jednáních s československým státem došlo v roce $1932 \mathrm{k}$ prodeji zámecké budovy pro armádní účely a svítala naděje také pro odkup nejcennějších sbírek - zbrojnice a knihovny. Celková hodnota bibliotéky byla oceněna částkou $650000 \mathrm{Kč}$, jednání však ztroskotala na negativním stanovisku ministerstva financí. ${ }^{43}$ Jelikož vojenská správa začala tlačit na urychlené vyklizení knihovního sálu, prodej knihovny do zahraničí byl státem zakázán a František Antonín trval na odprodeji bibliotéky jako celku a jejímu zaplacení v hotovosti, $\mathrm{z}$ r̆ady zahraničních i tuzemských zájemců zůstal nakonec pouze pražský starožitník Václav Hořejš, jemuž byla knihovna prodána za $330000 \mathrm{Kč}$ dne 2. února 1933. ${ }^{44}$ Hořejš zakoupil knihovnu kvůli jejímu rozprodání a finančnímu profitu, za kterýmžto účelem oslovil Karla Zinka, jenž měl soubor co nejrychleji připravit k prodeji. Ve značném spěchu tak proběhla XXXIII. Zinkova aukce za odborné spoluúčasti B. Lifky, jejímž zlatým hřebem se stal prodej benátského prvotisku Dekameronu z roku 1492 za osminásobek vyvolávací ceny zahraničnímu obchodníkovi Otto Ranschburgovi, jímž byl následně prodán do Itálie. ${ }^{45}$ „Hořejš ovšem nebyl ani tak spokojen. Nechtěl se zatěžovat pečlivou př́pravou aukcí a zejména tiskem katalogů. Knihy chtěl prodávat ve velkém, na metry a na kila, nikoliv po jednotlivých kusech. Proto se se Zinkem rozešel a organizaci dalších aukcí svěřil Oldřichu Pyšvejcovi. "46 Dražby konkurenční firmy již nedosahovaly Zinkovy úrovně a tituly, které se do nich nedostaly byly rozprodány „deprimujícím způsobem“. ${ }^{47}$ Skončily ve sklepení Hořejšova podniku, kde o ně sváděli urputné boje obchodníci domácí i zahraniční. ,V určenou hodinu se otevřely dveře, dav zákazníků sestoupil do sklepa, kde po celý den vládl chaos. V̌̌ichni kupující byli obchodníci, celí řiční, jak na dalším prodeji knih vydělají. Při Hořejšových cenách se nemuseli bát prodělku. Místo rozvážného premýšlení tak pobihali mezi regály ve snaze objevit co nejcennějši svazky dř̀ve než konkurence. Voboru vzácných knih byl,Hořejšưv sklep 'největším honem za poklady té doby, co Napoleonova vojska vyplenila knihovny v Itálii. Opakovaně propukaly šarvátky. Jeden obchodník uchopil knihu a hned tři dalši protestovali, že patři jim. Vzhledem $k$ tomu, že účastníci pocházeli z celé Evropy, létaly vzduchem výhružky a nadávky v nejrůznějšich jazycích. Nakonec skupina německých obchodniků přišla se smírným návrhem: sklep se rozdéli do nékolika sekcí a každému bude pridělena jedna s právem prednostního výběru. Poté, co si vybere, bude zbytek $k$ dispozici všem ostatním $[\ldots] \cdot{ }^{48} \mathrm{Ne}$ všechny tituly thunovské knihovny se dostaly do zahraničních sbírek a řadu z nich získali domácí sběratelé O. Kruliš-Randa, Otakar Vaňura, Rudolf Hirsch, Zdeněk Kalista ad. či československé státní instituce - Vojenské muzeum (dnes uloženo v Knihovně Vojenského historického ústavu), bratislavská Knižnica Univerzity Komenského, ČSZA či VUK, jejíž ředitel měl zájem především o sbírku knihovny Františka Martina Pelcla (1734-1801). ${ }^{49}$ Nakonec se VUK podařilo získat z thunovských sbírek čtyři inkunábule a 134 rukopisů o 137 svazcích celkem za 127500 Kč, pro které byla v oddělení rukopisů a starých tisků vytvořena samostatná signaturová skupina XIX.$^{50}$ Prodej majetku Thun-Hohensteinů se měl dotknout také dalšího velkého komplexu - empírového zámečku Kačiny na Kutnohorsku patřící Quido Thun-Hohensteinovi z italské rodové větve. Zámek šel sice do prodeje, avšak knihovna o cca 35000 svazcích po zdlouhavých jednáních nakonec zůstala zachována jako celek díky intervenci státu.

Kromě aukcí obsáhlých knižních komplexů Pálffyů, Ditrichsteinů a Thun-Hohensteinů, došlo také k rozprodeji menších zámeckých biblioték, jako např. Valdštejnů z Čestic (prodej v roce 1924); Sweerts-Sporků z Lysé nad Labem (asi 1000 svazků, prodej v Praze, 1926); Wallisů z Kolešovic (asi 1 000, prodej a aukce v Praze, 1927); Clam-Martiniců ze Smečna (asi 2 000, prodej v Praze, 1926, 1930); Medňanských (Mednyánszky) z Rakovic (asi 1000 , prodej na Slovensku a v Praze, 1931); Chorinských ze Želetic (asi 1 000, prodej a aukce v Dörlingu v Hamburku, 1932); Josefa Augusta Doerra ze Smilkova (prodej v roce 1932); Josefa Nostitze-Rienecka z Rokytnice a z Plané u Mariánských Lázní (aukce a prodej v Praze 1933-1934); Emmy Destinové ze Stráže nad Nežárkou (prodej části sbírky v roce 1934); Apponyiů v Oponicích na Slovensku (prodej části sbírky v Praze v roce 1939). ${ }^{51}$

\section{8-1945}

Politika appeasementu západních evropských mocností s cílem zabránit válce za jakoukoliv cenu společně se stupňujícím se nátlakem nacisti̊ na domácí i mezinárodní politické scéně, vyústily v podepsání dohody čtyř mocností

\footnotetext{
${ }^{41}$ I. poř́ádaná Karlem Zinkem v Praze ve dnech 10.-13. 4. 1933 (draženo 845 čísel), II. pořádaná O. Pyšvejcem v Praze ve dnech 6.-9. 6. 1933 (s př́́davky draženo 875 čísel); III. pořádaná O. Pyšvejcem v Praze ve dnech 4.-6. 10. 1933; IV. pořádaná O. Pyšvejcem v Praze ve dnech 6.-8. 11. 1933; V. pořádaná O. Pyšvejcem v Praze ve dnech 31. 1.-3. 2. 1934; VI. pořádaná K. Zinkem v Praze ve dnech 4.-7. 4. 1934.

${ }^{42} \mathrm{~K}$ problematice určení množství titulů srov. LEDINSKÁ-MALÁ 1971, s. 65-66.

${ }^{43}$ ŠUMAN 2016, s. 105.

${ }^{44}$ ŠUMAN 2016, s. 104-105; LEDINSKÁ-MALÁ 1971, s. 69-70.

45 ŠUMAN 2016, s. 106.

${ }^{46}$ Tamtéž, s. 105.

${ }^{47}$ LEDINSKÁ 1974, s. 207.

${ }^{48}$ Ze vzpomínek Hanse Petera Krause - srov. ŠUMAN 2016, s. 105-106.

${ }^{49}$ Tamtéž, s. 106-107.

${ }^{50}$ Tamtéž, s. 106.

${ }^{51}$ Srov. LIFKA 1933, s. 130; LIFKA 1934, s. 17.
} 
v Mnichově v noci z 29. na 30. záŕí 1938. V jejím důsledku bylo ČSR nuceno postoupit Německu pohraniční území a o svůj díl kořisti se přihlásilo i Polsko a Mad'arsko. Zábor zásadním způsobem narušil hospodářskou výrobu, komunikační sítě a nakonec zasáhl také vnitrozemské oblasti s tzv. německými jazykovými ostrovy. Celkově se týkal asi $20 \%$ předmnichovského území s 3819000 obyvateli. ${ }^{52}$

Kromě ekonomických ztrát došlo odstoupením sudetského území také k nezacelitelným kulturním škodám, které se dle B. Lifky dotkly asi 126 významných historických, vědeckých, klášterních a zámeckých biblioték s nejméně 1194526 knižními jednotkami. Z tohoto počtu tvořily 48 klášterní knihovny, 16 význačné farní a duchovenské bibliotéky a 42 knihovny archivní, muzejní a speciální. K nim bylo nutné počítat také 18 šlechtických a 2 sídelní soukromé zámecké knihovny:

- Čechy: Schwarzenberská v Českém Krumlově (asi 51000 svazků), Lobkowiczská v Bílině, Löwenstein-Wertheim-Rosenberská v Boru u Přimdy, Hohenzollernská v Bystřici nad Úhlavou, Zedtwitzovská v Doupově, Buqoyů v Nových Hradech a Hauenštejnu (Horní Hrad nedaleko Stráže nad Ohří), Beaufort-Spontinská v Bečově (4 000 sv.), Coudenhovská v Ronšperku (Poběžovice, 1500 sv.), Clary-Aldringenská V Teplicích (5 000 sv.), Hartigovská v Mimoni (4 000 sv.), Hohenlohská v Červeném Hrádku (1 000 sv.), Czerninská v Petrohradu na Lounsku (5 000 sv.), Kounicovská-Schönberská v Novém Zámku u České Lípy, Metternichovská v Kynžvartu (37 000 sv.), knihovna státního zámku v Zákupech (1 370 sv.),

- Morava: Žerotínská v Bludově (6 148 sv.), Řádu německých rytírů v Sovinci (17 422 sv.),

- soukromé: Eduarda Langera-Schrolla v Broumově (40 000 sv.) a Jaromíra Rašína v Liběchově (22000 sv.)..$^{53}$

Vyhlášení Protektorátu Čechy a Morava, samostatného Slovenského štátu a autonomní Podkarpatské Rusi proniklo do všech oblastí každodenního života obyvatel, který se měl např́íště podřídit germanizaci, arizaci a válečné kampani Třetí říše. Knihovnám všech stupňů bylo určeno přispívat k šíření ,,ríšské myšlenky“ a z jejich fondů bylo odstraňováno „škodlivé písemnictví“ - díla židovských autorů, politických emigrantů, literatura zednářská, legionářská, socialistická atp. Nejcitelnější ztráty, odhadované na půldruhého milionu svazků, postihly židovské majitele. ${ }^{54}$ Účinnou záchranou konfiskovaných knihoven bylo jejich odevzdání do univerzitních knihoven v Praze a v Brně, které si vyžádaly předání svazků (zejm. cenných tisků) pro doplnění mezer ve stávajících fondech. Zbytek byl posléze předán do stoupy, za což ručili představitelé okresního úřadu, nebo vládních policejních institucí ${ }^{55}$ Naštěstí se řadu knih perzekvovaných vlastníků či emigrantů podařilo uschovat a k jejich odevzdání úřadům došlo po okupaci, ${ }^{56}$ popřr. již za války zaměstnanci knihoven skryli svazky určené ke zničení před zraky okupantů, jako tomu bylo napr. v brněnské Veřejné knihovně a čítárně: „Při policejnich opatřenich bylo zabaveno celkem 1140 svazkủ knih povétšinou povahy politické a ideologické. Byly odvezeny policejními orgány a do knihoven se již nevrátily. To jest také celková skutečná ztráta knižniho materiálu. Pokud později docházelo k označování knih, které měly býti z knihoven vyrazovány a odstraňovány, podařilo se správě knihovny po mlčenlivé dohodě s českými výkonnými orgány policejního ředitelství podržeti všecky k zabaveni určené knihy pod strechou knihovny. Byly uschovány ve zvláštních balících a vhodně rozmistěny po budově $z$ di̊vodu nenápadnosti. Podobně byla zachráněna veškerá literatura ruská, anglická, americká a francouzská, jejižz půjčováni bylo zakázáno. " ${ }^{57}$

Úbytky fondů se dotkly knihoven všech typů: vědeckých, veřejných, korporačních, administrativních či soukromých. ${ }^{58}$ Citelně postiženy byly mj. Karlova univerzita a Masarykova univerzita, České vysoké učení technické, Akademie výtvarných umění, Vysoká škola báňská v Příbrami, Vysoká škola technická dr. Edvarda Beneše, brněnská a pražská Vysoká škola zemědělská, Náprstkovo muzeum, Československá akademie zemědělská, Ústřední svaz československého průmyslu, Ústav pro národní biologii a eugeniku v Praze, knihovny ministerstev zahraničních věcí a financí, lužická bibliotéka dr. Františka Páty či Československé obce sokolské. Ze zámeckých knihoven je pak nutné zmínit bibliotéku hrabat Šporků z Kuksu převezenou do Lince či vzácnou roudnickou lobkowiczkou knihovnu zabranou v roce 1941 protektorátní správou. Díky úsilí NUK byla knihovna evakuována do jejích depozit (přes 72000 svazků), v nichž zůstala i po válce a k navrácení její značné části Lobkowiczům došlo

\footnotetext{
52 DEJMEK 2018, s. 256-257.

${ }^{53}$ LIFKA 1938, s. 120-121.

${ }^{54}$ Zásahy do vlastnických vztahů po Mnichovu a zejména po 15 . březnu 1939 byly součástí nacisty prováděné okupační politiky, která směřovala jak vůči židovskému, tak i českému majetku. Majetkové přesuny se nesly v duchu vyvlastňování a konfiskací, nápadně nevýhodných a nedobrovolných prodejů či př́padné nucené správy. Po celou dobu existence protektorátu byl téměř veškerý nemovitý majetek (napřs. Státních lesů a statků) převeden na instituce kontrolované německou okupační správou a ve prospěch německých subjektů byly pružně využivány také další německé trestní normy, soudní rozsudky či ustanovení vyplývající z provádění první pozemkové reformy. V roce 1941 vznikl v Praze tzv. Treuhandstelle, zvláštní úřad pro evidenci a správu majetku ponechaného $\mathrm{v}$ protektorátu po počátku transportů, $\mathrm{k}$ jeho běžné činnosti patřilo soustředění a soupis zabavených knih na území Prahy, nadto začala v prosinci 1942 akce TS06, která byla zaměřena na zajištění knih i v rámci dalších oberlandrátů. Knihy měly být očištěny a opraveny, odstraněny ex libris. K jejich zhodnocování mělo dojít prodejem sestavených kompletů, nepoužitelné písemnosti byly soustřed’ovány jako starý papír. Do března 1943 bylo ve skladech téměř 800 tisíc svazků knih všeho druhu, srov. KREJČOVÁ - VLČEK 2007, s. 26-40; KUKLÍK 2010, s. 86-87.

${ }^{55}$ DOLEŽAL 1996, s. 119.

${ }^{56}$ Např. Josef Hrubý (1899-1975), dlouholetý funkcionář KSČ, předválečný člen jejího ústředního výboru a poslanec Národního shromáždění, byl po zákazu KSČ koncem roku 1938 pověren nalezením úkrytu pro svazky z knihoven předních stranických funkcionářů - Bohumíra Šmerala, Rudolfa Slánského, Jana Švermy či Viliama Širokého. KOKEŠ 2018, s. 480.

${ }^{57}$ ŘEZNÍČEK 1945, s. 183. Dále srov. např. ŠIMEČEK - TRÁVNÍČEK 2014, s. 307-308.

${ }^{58}$ ČERNÁ 1946, s. 302.
} 


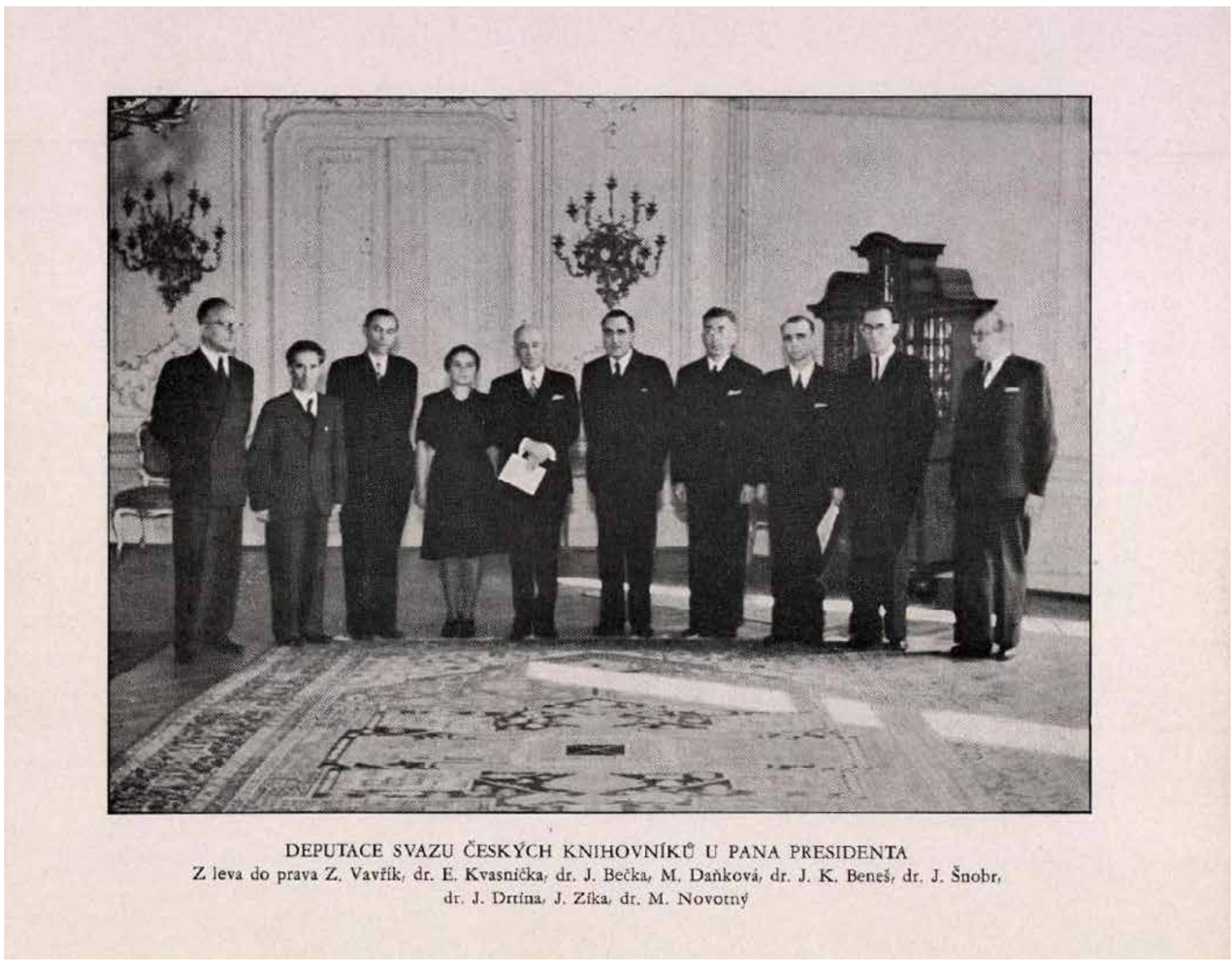

Obr. 2. Návštěva zástupců Svazu českých knihovníků u prezidenta Edvarda Beneše ze dne 11. 10. 1945. Knihovna. Časopis Svazu českých knihovníků 1, 1945. č. 2.

až v letech 1992 až 1994. V současnosti je uložena na zámku v Nelahozevsi, se svými cca 65000 svazky jde o největší zámeckou knihovnou v České republice, patř́cí vůbec k nejstarším šlechtickým knihovnám ve stř̌ední Evropě. ${ }^{59}$

Kontrola a znepřístupňování knižních fondů okupanty formou zavírání celých knihoven či jejich slučováním se Zemskou a univerzitní knihovnou, jejíž výpůjčky byly dozorovány Němci, mělo svá pozitiva alespoň v tom, že se přejaté kulturní statky podařilo zachránit před možným zničením či zavlečením do Říše. V tomto kontextu je nutné zdůraznit, že univerzitní knihovny v Praze a Brně přečkaly válku bez výraznějších ztrát i díky tomu, že sloužily německým vysokým školám v obou metropolích. ${ }^{60}$

$\mathrm{V}$ důsledku hrozby spojeneckého bombardování a po neblahých zkušenostech se zničením německých knihoven v Berlíně, Mnichově či Drážd'anech a opakovaným náletům na průmyslové oblasti protektorátu (např. na Mostecku, v Plzni, Pardubicích) uložili okupanti protektorátním úřadům evakuaci archivních, muzejních a knižních sbírek na venkov. Přechodným domovem cenných knižních souborů pražské NUK, Národního muzea či brněnské MUK se tak staly zámky a kláštery na Karlštejně, ve Zlaté Koruně (zde mj. deponována výše uvedená lobkowiczská knihovna), v Pohledu na Havlíčkobrodsku, Slatiňanech na Chrudimsku, Lysé nad Labem, Lánech, Křivoklátu, Mníšku, Průhonicích, Veltrusech, ve Žlebech, v Třešti, ve Žd'áru nad Sázavou či Černé Hoře na Blanensku, kam byly uloženy nejvzácnější knihy (napřr. zednářská sbírka hraběte Auersperga), z nichž některé byly Němci při ústupu rozkradeny. Naštěstí se značná část ukrytých knižních titulů zachovala a po válce došlo $\mathrm{k}$ jejich pozvolnému návratu do dřívějších destinací, ${ }^{61}$ o čemž krátce referovali také představitelé Svazu československých knihovníků při audienci u prezidenta E. Beneše dne 11. ř́ijna 1945: „Předseda Svazu mu vyložil, že největši pražské knihovny přiliš poškozeny nebyly. Knihy zakázané Němci byly sice z knihoven vyřazovány, ale podařilo se

\footnotetext{
${ }^{59}$ ČERNÁ 1946, s. 303; MÖSTL 2009, s. 19-20; Internetový portál Virtuální rekonstrukce knižních celků - roudnická lobkowiczská knihovna. Dostupné z: https://provenio.net/records/ab36e2d8-ea5d-46ee-a43c-26848c3fd593 [cit. 30. 11. 2020].

${ }^{60}$ ČERNÁ 1946, s. 302; DOLEŽAL 1996, s. 119-120.

${ }^{61}$ ČERNÁ 1946, s. 303-304.
} 
na mnoha mistech tyto knihy zachránit. Některé knihovny nebo jejich části byly evakuovány mimo Prahu před leteckým bombardováním. ,Mně ukradli Němci všechny moje knihy', pravil pan prezident [...] Na dotaz, je-li snad néjaká naděje, že by mohly být tyto knihy nalezeny, informoval pana prezidenta dr. Drtina, že mnoho knih, které zabavilo gestapo, mélo být odvezeno do Hitlerova muzea $v$ Linci. $V$ Českých Budějovicích je ještě několik beden, které měly být odvezeny a nedošlo již k tomu. Americká armáda ted' soustřed'uje všechny knihy a umělecké předměty do Mnichova. Dr. Novotný upozornil, že knihy soustred'ovala také německá ,Sicherheitdienst' a ukládala je na různých místech. "62

Nejen tuzemské fondy podlehly evakuaci. Na území poválečného Československa se postupně nacházelo množství zahraničního knižního majetku. $\mathrm{V}$ důsledku protileteckých opatření bylo do kláštera Teplá odvezeno na 400 tisíc svazků Pruské státní knihovny. Snahou československých orgánů bylo ponechání této knihovny jako reparačního majetku, nicméně knihovna byla nakonec odvezena americkou armádou bez možnosti zásahu čs. strany. Torza Berlínské městské knihovny (Stadtbibliothek Berlin) byly nalezeny nedaleko Šumperka v odstavených vagonech, další část jejích fondů na zámku Frýdlant. ${ }^{63} \mathrm{Z}$ jiných knihoven, které zastihl konec války našem území, můžeme jmenovat části fondů Německé pedagogické knihovny (Deutsche Lehrerbücherei und Pädagogische Zentralbibliothek) nebo Německé lékařské knihovny (Deutsche Ärzte Bücherei). Valná většina těchto knih se vrátila v poválečném období do Německé demokratické republiky, část splynula s fondy československých knihoven. ${ }^{64}$

Nejvíce knih však bylo soustředěno na čtyřech severočeských zámcích - Housce, Mimoni, Novém Berštejnu a Novém Falkenburgu. Jednalo se o depoty 7. odboru (Amt VII) Hlavního říšského bezpečnostního úřadu (Reichssicherheitshauptamt - RSHA). ${ }^{65}$ Jejich správy se zhostila Národní a universitní knihovna, část těchto fondů byla na základě provenienčních znaků restituována, zřejmě větší část získala pro své fondy právě NUK. ${ }^{66}$

Přestože zabráním pohraničí a okupací vznikly českému (resp. československému) knihovnictví významné ztráty, ${ }^{67}$ situace byla relativně lepší oproti jiným evropským státům, v nichž docházelo $\mathrm{k}$ soustavnému ničení a konfiskacím knižního materiálu, několikerému přechodu válečných front a soustavnému nacistickému či spojeneckému bombardování. Nacisté považovali knihovny protektorátu za své vlastnictví a nástroj převýchovy českého obyvatelstva, ve své barbarské devastaci kulturních hodnot tedy nešli až na „samé dno“, jak tomu bylo v zemích východní Evropy, zejména v SSSR, Polsku a Jugoslávii. ${ }^{68}$

\section{$1945-1954$}

V třetí Československé republice vymezené obdobím května 1945 až února 1948 vládly politické, hospodářské a sociální poměry nesoucí se na vlně celoevropských trendů posunu do levé části politického spektra, socializace, částečného znárodňování, nenávisti k Němcům a výrazného posílení komunistických stran. V tuzemském veřejném životě se stala všudypřítomnými hesla o „národní a demokratické revoluci“"vzešlé z protinacistického tažení a proklamující př́íchod nového společenského uspořádání. Politický systém ztělesněný širokou Národní frontou Čechů a Slováků zakotvenou v Košickém vládním programu se měl do budoucna politicky, hospodářsky, sociálně i kulturně rozejít s prvorepublikovými poměry, které nedokázaly zabránit „,partajnictví“, byrokratizaci, ekonomickým propadům či protistátní činnosti henleinovců a v konečném důsledku i rozbití Československa a okupaci. Např́ŕště měly být všechny segmenty veřejného života odpovědny výhradně „lidu“, jímž byli kontrolovány a jemuž sloužily. Všeobecně se začala prosazovat ,kolektivita“" nad ,individualitou“, do každodenního života zasáhla retribuce a do toho hospodářského socializace, zahraniční politika se orientovala na SSSR, bezpečnostní složky a armáda se postupně dostaly do rukou komunistů, kteří se stali rozhodující politickou silou. Svůj mocenský triumf nakonec slavili v únoru 1948, kdy se jim díky převratu podařilo ovládnout všechny státní struktury. Období komunistické vlády v letech 1949 až 1953 pak můžeme označit př́vlastkem „totalitní“, nebot' splňovalo všech šest souběžně působících základních typologických znaků totalitního státu - oficiální ideologie, jediná masová politická strana splývající se státem, kontrola společnosti prostřednictvím tajné politické policie uplatňující teror, monopol na šíření a interpretaci informací, monopol na prostředky ozbrojené moci společně s kontrolou a centrálním řízením ekonomiky. ${ }^{69}$

Zásadními legislativními normami umožňujícími poválečné majetkové přesuny, byly dekrety prezidenta republiky, na jejichž základě byl konfiskován majetek „osob státně nespolehlivých“. ${ }^{70}$ Předzvěstí bylo vydání dekretu prezidenta republiky č. 5/1945 Sb., o neplatnosti některých majetkově-právních jednání z doby nesvobody a o národní správě majetkových hodnot Němců, Mad’arů, zrádců a kolaborantů

\footnotetext{
${ }^{62}$ KNIHOVNA 1945a, s. 49.

${ }^{63}$ Nejpodrobněji k zámku Frýdlant srov. REJHA 2017.

${ }^{64}$ STROUHALOVÁ 2017, s. 9-11.

${ }^{65}$ Více ke knihovně RSHA STROUHALOVÁ 2017a, s. 30-37.

${ }^{66}$ Více k výzkumu a jeho možnostem STROUHALOVÁ, 2020.

${ }^{67}$ Co se týká rozvrácení obecních knihoven, byly celkové škody vyčísleny v roce 1946 takto: zcela nebo částečně bylo postiženo 9508 obecních knihoven, ztráty se týkaly 3337819 svazkủ v hodnotě 166890000 Kčs a škody na budovách a jiném zařízení se vyšplhaly do výše 12160000 Kčs, srov. STROUHALOVÁ 2016, s. 18.

${ }^{68}$ DOLEŽAL 1996, s. 121

${ }^{69}$ FRIEDRICH - BRZEZINSKI 1996, s. 225-236.

${ }^{70}$ Pojem konfiskace se v československém právu po druhé světové válce použil pro plošná, nucená vyvlastnění bez náhrady na základě legislativních norem. Ty definovaly dané kategorie osob, na které se konfiskace majetku vztahovala. Oproti předchozím historickým př́ipadům, kdy byl majetek zabaven pro panovníka (resp. stát), se poválečná konfiskace lišila v tom, že konečným př́jemcem zabaveného majetku neměl být stát, ale noví vlastníci z řad fyzických a právnických osob. Srov. KUKLÍK 2010, s. 12-13.
} 
a některých organizací a ústavů ze dne 19. května 1945. Majetek byl dán pod národní správu, původní vlastník jej držel pouze formálně a nemohl s ním dále disponovat. ${ }^{71}$ V červnu byl vydán dekret prezidenta republiky č. 12/1945 Sb., o konfiskaci a urychleném rozdělení zemědělského majetku Němců, Mad’arů, jakož i zrádců a nepřátel českého a slovenského národa, ${ }^{72}$ na jehož základě byl zabrán zemědělský majetek. Podle $\S 4$,,zemědělským majetkem jest rozuměti zemédèlskou a lesní pi̊du, k ní patřící budovy a zařizení, závody zemédělského průmyslu, sloužicí vlastnímu zemédělskému a lesnimu hospodářství, jakož i movité přislušenství (živý a mrtvý inventář) a všechna práva, která jsou spojena s držbou zkonfiskovaného majetku anebo jeho části. “"

Poslední normou z bezprostředně poválečného období s dopadem na majetkové vztahy byl dekret prezidenta republiky č. 108/1945 Sb., o konfiskaci nepřátelského majetku a Fondech národní obnovy. Vydán byl dne 25. rríjna 1945 těsně před obnovením činnosti Národního shromáždění a jednoznačně přinesl největší zásah do vlastnických vztahů. Bez náhrady konfiskoval pro Československou republiku majetek movitý i nemovitý včetně práv s nimi souvisejících, s výjimkou majetku sloužícího k zajištění životních potřeb nebo k vykonávání zaměstnání dekretem postižených osob a jejich rodinných př́slušníků. ${ }^{73}$ Dekret se nevztahoval na majetek již dřive zabraný podle dekretu č. 12/1945 Sb. Ke správě a obstarávání úkolů souvisejících $\mathrm{s}$ jeho prozatímní správou byl zřízen Fond národní obnovy (dále často jen FNO), který následně majetek rozdělil $v$ príílělovém řízení za úhradu.

Stejně jako po první světové válce i po roce 1945 proběhly rozsáhlé státní zásahy do pozemkové držby půdy. V různých variacích se pozemkové reformy odehrály ve všech evropských zemích stižených tzv. lidově demokratickou revolucí. V Československu se pozemková reforma odehrála ve třech etapách: 1. v letech 1945-1946 (na Slovensku do r. 1948), během níž došlo ke konfiskaci půdy „Němců, Mad'arů a zrádců“ a jejímu přidělení tuzemským zájemcům z řad fyzických a právnických osob; 2. v letech 1947-1948 označovaná jako, ,revize pozemkové reformy z první republiky“ postihující zejména majetek šlechty získaný před rokem 1918; 3. po únoru 1948 - tzv. nová pozemková reforma s omezeným vlastnictvím do padesáti hektarů, která splynula s nastupující kolektivizací zemědělství. ${ }^{74}$

Pro pochopení problematiky konfiskace knih a knihoven $\mathrm{v}$ poválečném období je $\mathrm{v}$ prvé řadě třeba rozlišovat, podle které zákonné normy přešel majetek do vlastnictví státu a zároveň v jakém období. Správa těchto kulturních hodnot byla vedena po dvou pomyslných liniích, v nichž figurovala řada institucí činících si na ně dispoziční nároky, přičemž početnější skupinou byly knihovny konfiskované dle dekretu prezidenta republiky č. 108/1945 Sb. Pro zjednodušení si můžeme představit, že každá kniha, jejímž původním vlastníkem byla osoba německé národnosti, nebo veřejná i soukromá německá korporace, přešla do vlastnictví československého státu. Méně zastoupenou co do počtu, nikoliv však co do hodnoty, byla skupina knih zabraných podle dekretu prezidenta republiky č. 12/1945 Sb., spjatá s původními šlechtickými sídly, kterou pro maximální zobecnění označíme jako zámecké knihovny. Ve správě obou skupin knih a knihoven nacházíme mnoho společných činitelů. Zásadním pojítkem nakonec bylo zřízení Národní kulturní komise (dále jen často NKK), která měla v důsledku stejnou pravomoc pro obě skupiny knižního materiálu.

První měsíce po osvobození se nesly ve znamení chaosu, jenž zachytil ve svých pamětech např. prof. PhDr. Václav Černý (1905-1987) působící po válce do roku 1946 jako referent pro školství a kulturu při pražském Zemském národním výboru (dále jen ZNV): „Celý vyděšen, přikvačil z České Skalice starý přtel Jan Krtička: čeled' ratibořického dvora a zámečku si mezi sebe už už parceluje na orné a lučni podíly Babiččino údolí, náchodského knižete Schaumburga-Lippe zavřli nejdřiv do klece skleníku v parku, pak si ho náchodští odvezli, propustili ho a vyhnali, stařec osmdesátiletý, zcela opuštěný, se dopližil pěšky přikopem, ještě stále proti toku valíci se sovětské armády, přes kladské hranice na zámeček slezsko-německý hraběte Magnise v Jelenově, a tam za pár hodin vyčerpáním zemřel. Na mistě jsme sestavili dekret, jímž ZNV prohlašoval Ratibořické údolí se zámkem, mlýnem, Starým bělidlem, Rýzmburkem za národni kulturni majetkovou rezervaci, a Krtička uháněl s mým podpisem na ministerstvo školství a osvéty pro potvrzení člena vlády - co pozemského zůstalo z dětství Boženy Němcové bylo zachráněno před zkázou, a snad nikoliv jen pro výletni zájezdy jednotlivých zemédělských družstev a novodobých školáků, kteři ,Babičku' nikdy nedočetli [...] Včerejši panská čeled’ se chovala všude stejně a hưr̆, český zemědělský podruh se v květnu nadobro opil revoluční mocí, ,znárodňoval', vyvlastňoval, okupoval, rozkrádal, vyhazoval, rádil. "75

Mnoho zajištěných subjektů pod národní správou tedy zůstalo opuštěných, především z důvodů útěku původních vlastníků před postupující frontou nebo následkem tzv. divokého odsunu. $\mathrm{V}$ případě památkových objektů a uměleckých předmětů naráželo zajišt’ování na základní problém, kterým byla nevyjasněnost kompetencí mezi jednotlivými státními orgány. Je třeba zdůraznit, že žádný z tehdejších subjekti̊ systému památkové péče neměl pravomoci, prostředky ani personální kapacitu k zajištění a zabezpečení těchto

\footnotetext{
${ }^{71}$ Za osoby státně nespolehlivé byly považovány osoby: německé nebo mad’arské národnosti, vyvíjející činnost směřující proti státní svrchovanosti, samostatnosti, celistvosti, demokraticko-republikánské státní formě, bezpečnosti a obraně Československé republiky. Dále osoby k takové činnosti podněcující nebo ty, které chtěly jakýmkoli způsobem záměrně podporovat německé a mad’arské okupanty. Za státně nespolehlivé právnické osoby se pokládaly ty, jejichž správa úmyslně a záměrně sloužila německému nebo mad’arskému vedení války nebo fašistickým a nacistickým účelům. Za Němce a Mad’ara byl považován každý, kdo se při sčíání lidu v roce 1929 přihlásil k těmto národnostem, nebo se stal členem skupiny, útvaru či politické strany sdružující tyto národnosti.

${ }^{72}$ Dekret zahrnoval prakticky totožný okruh osob jako předchozí, v jeho dikci se však nehovořilo o státně nespolehlivých osobách, ale o zrádcích a nepřátelích republiky - jednalo se o projev trestněprávní problematiky vyžadující potrestání a sankce.

${ }^{73}$ V praxi šlo o oděvy, domácí nářadí, potraviny - viz §§1-2 dekretu č. 108/1945 Sb. K definici postižených subjektů více STROUHALOVÁ 2016, s. 25-29.

${ }^{74}$ Podrobně srov. PRŮCHA 2009, s. 71-103.

${ }^{75}$ ČERNÝ 1992, s. 32-33.
} 
památek. Do jisté míry tak tyto úkony závisely na osobní zodpovědnosti zúčastněných. Dalším úskalím byl nedostatek pohonných hmot a dopravních prostředků vůbec, včetně špatně fungující železnice, po níž se přesouvaly kontingenty sovětské armády, která u nás zůstala až do prosince $1945 .{ }^{76}$

V prvních poválečných týdnech se stal nejaktivnějším orgánem při záchraně kulturních a historických památek Sekretariát pro evidenci a záchranu uměleckých a historických památek (dále jen Sekretariát). ${ }^{77}$ Působil při archivní sekci Kulturní komise ${ }^{78}$ nově ustanoveného ZNV v Praze, ${ }^{79}$ v němž byly aktivně zapojeny osobnosti předválečného československého archivnictví. Popud k jeho vzniku dal vedoucí Archivu Národního muzea Jaroslav Charvát (1904-1988), který stál od počátku v jeho čele. Z dalších osobností musíme jmenovat ještě archiváře Miloslava Volfa (1902-1982) působícího v Archivu země České či Oldřicha Říhu (1911-1974) z téže instituce. Činnost Sekretariátu byla oficiálně zahájena 18. května 1945 a jeho hlavním úkolem byla evidence kulturních památek. Usiloval o zabezpečení sbírek a dokumentů pražských knihoven, archivů a sbírkových institucí, deponovaných před spojeneckým bombardováním do objektů mimo hlavní město, předmětů ukrytých nacisty na území protektorátu i v oblastech bývalé Říšské župy Sudety a o podchycení majetku obyvatel německé národnosti, kteří opustili svi̊j domov v závěru války. Sekretariát usiloval o soustředění informací o potenciálně ohrožených kulturních statcích, prostřednictvím rozhlasu a tisku vyzýval obyvatele $\mathrm{k}$ záchraně památek a shromažd'oval hlášení o jejich nálezech a možném ohrožení. Vzhledem k jeho „chudé“ personální obsazenosti, časovým a dopravním možnostem, spolupracoval po celou dobu své činnosti s pověřenými osobami v jednotlivých regionech. Zapojeni byli zpravidla lidé znalí místních poměrů a zainteresovaní v kulturním životě dané oblasti - jednalo se o muzejníky, archiváře, konzervátory státní památkové péče nebo např. okresní školní inspektory. Pověřenci zaměřili svou pozornost na muzea, městské či patrimoniální archivy a šlechtická sídla. Pokud existovalo povědomí o hodnotném kulturním vybavení domácností, pozornost se zaměřila i na vily továrníků či honosné byty. Pověřenci objekty prohlédli a o jejich vybavení, stavu a zajištění podali zprávu do Prahy. ${ }^{80}$ Při výkonu svých činností se obraceli na nově vznikající orgány státní správy - národní výbory, př́ípadně na bezpečnostní složky. S pomocí veřejných orgánů se vesměs podařilo kýžené objekty zajistit a v praxi byly často i klíče ke vstupu svěřeny do jejich další péče. ${ }^{81}$

$\mathrm{Na}$ počátku června 1945 považovali pracovníci Sekretariátu základní evidenci za víceméně ukončenou, nedisponovali však nástroji $\mathrm{k}$ reálnému zásahu $\mathrm{k}$ zajištění památek. ,Ochranářská činnost precházi totiž nyní po 5ti týdnech od revoluce z obdobi pouhého zajišstováni a evidence ve skutečnou činnost ochranářskou, která nemůže být zvládnuta dvěma úředníky v Sekretariátě, který není vybaven patřičnými prostředky hmotnými a do dnešního dne nedostal od Zemského úřadu ještě pres všechny urgence ani halére ani na kancelářskou agendu ani na plat Dru Řihovi, který po svém návratu z káznice byl zde na hodinový plat zaměstnán. “ Na společné schůzi archivní, muzejní, knihovnické a památkářské sekce kulturní komise ZNV bylo dohodnuto, že Sekretariát bude nadále fungovat jako společný orgán pro evidenci kulturních statků, ale v záležitostech vlastní výkonné kompetence dojde k rozdělení mezi specializované centrální instituce - péčí o archivy byl pověřen Archiv země České, muzei NM, které zároveň žádalo o dočasné pověření vrchní správou všech muzeí v pohraničí, knihovnami Národní a universitní knihovna (dále jen často NUK $^{82}$ ) stávajícími galeriemi Národní galerie a ostatními hmotnými památkami a zámky, které měly být opatřeny národní správou, Památkový úrad v Praze. ${ }^{83}$ Činnost Sekretariátu tedy zcela „neutichla“ a v určitých ohledech můžeme spatřovat i pevněji organizovanou agendu.

V průběhu června 1945 obeslal nejprve ONV, které vyzýval k „vyšetření stavu památkových objektů“ v jejich okresech. Ty měly upozornit MNV nacházející se $\mathrm{v}$ jejich spádových oblastech, aby zjistily škody způsobené na památkových objektech. Pozornost měla být věnována ,, $i$ vilám a sídlưm třeba novějšího původu, které náležely Němcưm a osobám státně nespolehlivým. Zpravidla obsahují uloupený český majetek at' veřejný či soukromý". Pokud tyto objekty nebyly dosud zajištěny, mělo tak být učiněno zásahem dotčeného národního výboru. ${ }^{84}$ Dne 1 . července 1945 , krátce po vydání dekretu prezidenta republiky o konfiskaci zemědělského majetku č. 12/1945 Sb., pak vyzval Sekretariát ONV v Čechách, aby okamžitě přikročily ,, $k$ zajištění zámků a jiných kulturních objekti̊ na zabraném majetku se nacházejicích “. Předměty spadající pod ochranu Památkového úradu měly nadále zůstat v jeho kompetenci a bez jeho svolení nesměly být prováděny změny na jejich vnějším i vnitřním vzhledu. ,Archivy, musea, obrazárny a jiné umělecké sbirky, nacházejicí se v inventárích zabraných objektů jsou důležitou národní hodnotou a třeba to není v presidentském dekretu výslovně konstatováno, jest nutno posuzovati je jako majetek celého národa. Není proto možno tyto umělecké hodnoty rozprodávati ve veřejných dražbách nebo jiným způsobem nebo prihližeti $k$ tomu, kterak jsou neodpovědnými činiteli

\footnotetext{
${ }^{76}$ Nedostatek je patrný z mnoha dokumentů poválečného období, srov. např. NA ČR, ZÚ, kart. 802, př́ípis Sekretariát č. j. 61 ze dne 23.5 .1945 adresovaný ministerstvu dopravy: „Protože k sváženi těchto památek je bezpodminečně nutné lehké kombinované vozidlo, doufá, že ministerstvo dopravy v pochopeni tohoto úkolu $k$ zabezpečeni státniho majetku udélá laskavé povoleni k použiváni motorového vozidla."

${ }^{77}$ K činnosti Sekretariátu více UHLÍKOVÁ 2019, s. 36-41; UHLÍKOVÁ 2004, s. $20-21$.

${ }^{78}$ Kulturní komise se skládala ze čtyř sekcí pro jednotlivá kulturní odvětví - archivní, památková, knihovní a muzejní.

${ }^{79}$ ZNV v Praze byl vytvořen 11. 5. 1945 z České národní rady - ta byla za okupace složena z vedoucích činitelů různých skupin domácího odboje a od 5. 5. 1945 do př́́chodu vlády ze Slovenska byla nejvyšší reprezentantkou státní moci na osvobozeném území.

${ }^{80}$ NA ČR, ZÚ, kart. 802 - průběžně, především opisy pověřovací listin jednotlivým osobám a zprávy o zajištění objektů.

${ }^{81}$ Tamtéž, průběžně.

${ }^{82} \mathrm{~K}$ vývoji názvu srov. výše.

${ }^{83}$ NA ČR, ZÚ, kart. 802, Přípis Sekretariátu předsedovi kulturní komise ZNV ze dne 14. 6. 1945 a Zápis o společné schůzi archivní, musejní, knihovní a památkářské sekce kulturní komise Zemského národního výboru v Praze konané dne 13. 6. 1945.

${ }^{84}$ Tamtéž, oběžníky adresované ONV uloženy průběžně.
} 
rozkrádány, rozbijeny nebo poškozovány [...] podle naši informace bude jakékoliv zcizeni uměleckých hodnot a historických památek anulováno a tyto vyhraženy pro přsilušné verejné ústavy a zařizení (Národní galerie, vlastivědná musea, archivy apod.). " 85

Můžeme se domnívat, že národní výbory výnosy a oběžníky Sekretariátu, potažmo ZNV v Praze, př́liš nereflektovaly. Dne 25. července 1945 byly totiž znovu upozorněny, aby všemi prostředky, které mají k dispozici, chránily historicky a památkově cenné objekty i př́rodní kulturní hodnoty: ,, Ochranou objektu rozumíme, aby památkový objekt i sad nebyl národním výborem propůjčován jako přechodný útulek vojenských jednotek a bezpečnostnich sborů jakékoliv národnosti. Ochrana se nevztahuje jen na vnějšek budovy, ale i na její zpravidla umélecké zařizení. "86 $\mathrm{K}$ jejich úsilí se postupně přidávaly i další subjekty. Sekretariát ukončil administrativně svou činnost v listopadu 1945 (fakticky zřejmě již dříve), o čemž informoval ZNV: ,činnost tohoto Sekretariátu [...] skončila, nebot' agenda, kterou v porevoluční době zastával, vzala za své [...]. " 87

Spisový materiál Sekretariátu je v oblasti záchrany knižního majetku poněkud chudší v porovnání s agendou týkající se zajištění archivů a muzeí. ${ }^{88}$ Dochované jsou zprávy o zajištění obecních německých knihoven, muzejních knihoven, ale i o depotech zahraničního knižního materiálu na zámcích v severních Čechách (srov. výše). ${ }^{89}$ Druhou kategorii zpráv potom tvoří informace o knihovnách v ohrožení, jako např. na zámku Kačina. Sekretariátu byly podány zprávy o jeho drancování v souvislosti s přítomností Rudé armády, která měla místním obyvatelům rozdávat zámecké zařízení. Do objektu se tedy 28. května 1945 vydal J. Charvát, jenž na místě zjistil, že zámek zůstal neporušen, a to včetně knihovny, v níž sice posádka umístila několik pytlů sucharů, knihy však nijak neutrpěly. ${ }^{90}$ Dlužno ovšem poznamenat, že po odchodu sovětské posádky o necelý měsíc později byla situace zcela jiná: ,je rozbito několik okennich skel, žaluzie a několik mistnosti násilně vypáčeno. V souterreinu nalezeno mezi rozbitým nábytkem množství rüzných zbraní a střeliva, $v$ kuchyni mnoho zahnivajících potravin. Poškozený mobiliář - nejtiže poškozená křesla a pohovky, z nichž jsou servány potahy. Koberce chybí vesměs, ze sbirek porcelánu zbyly jen nepatrné zbytky, jídelna zůstala bez nádobí a př́borů... "91

Ještě méně ucelených zpráv nacházíme o zámeckých knihovnách. Výjimkou je např. knihovna patřící Richardu Nicolasovi Coudenhove-Kalergi (1894-1972) na zámku v Poběžovicích (dřive Ronšperk): „Knihovna je umistěna ve dvou sálech v I. patře ústřední zámecké budovy. V první místnosti jsou většinou dila encyklopedická a charakteru exotického (angl., franc., něm., i jap. atd, v druhé místnosti odborná a nauková literatura histor., zeměp., národop., práv., nábož., zool., zeměděls., umělecká, lovecká (něm., franc., angl.). Knihy pocházejí přvéážně z 19. a z počátku 20. stol. Asi pětina knih patř́ stol. 17. a 18. Je tu také něco bohemik (německy psaných, jde o dila vlastivědná a právnická.) Poměrně hodně je tu staršich edic antických klasiků. Inventár byl kdysi začat, není však dokončen. Vobou sálech je jakýs takýs pořádek, nic nesvědči o krádežích nebo jiných zásazích. Okna obou sálů jsou zdravá. “92

Není cílem předkládané práce podat kompletní rozbor zapojených institucí s výčtem všech směrnic, které byly v letech 1945-1947 vydány. Nebylo by to snad ani možné. Jestliže se nám mohly první týdny po ukončení války zdát poněkud nepřehledné, následující období se potom jeví zcela nelogické. Ne vždy nám prameny napovídají, zda k určitému jednání došlo ve vzájemném konsenzu zapojených subjektů, nebo zda pouze nebyly domyšleny hlubší souvislosti některých nařízení, o čemž zřejmě nejlépe vypovídá dopis MNV v České Kamenici adresovaný NKK: „, Sebrali jsme knihy, pokud se v tom revolučním chaosu a nedostatku lidí sebrat daly. Nesepsali jsme je a neroztř́dili, jen jsme stačili zjistit počet. Kdo je měl podrobně sepsat a odborně roztř́dit? Kdo to mél zadarmo udělat při 32.000 knihách? Nařizení chodila, ale kdo bude síly honorovat, když jsme zde pensisty neměli, nikdo nám neporadil. Vmyslete se v naši situaci a pochopte, jak nám bylo. $S$ velkou námahou a nemalým vydáním $M N V$, vedle dobrovolné práce mojí i p. Pšeničky, domovníka v museu, s vědomím, že zachraňujeme cenný národni majetek, a tu když o dokončené práci podáme zprávu, nedostaneme odpověd'. Nebo dojde oběžník, prodáno do stoupy, prodáno panu Bondymu, prodáno Orbisu a nakonec, že je to Vaše " "93

Pro zajištění knih pod národní správou byla pověřena v červnu 1945 NUK (viz výše). Velmi záhy nechala za souhlasu Sekretariátu rozšíriit rozhlasovou a tiskovou zprávu, kterou žádala, aby všechny místní a okresní národní výbory, prrípadně jiné úřední orgány ochránily knižní materiál ze zabavených knihoven veřejných i soukromých před zkázou a aby o nich podávaly zprávy do Klementina. Stala se tak hlavním činitelem při zajišt’ování knih ze soukromých i veřjejných knihoven. ${ }^{94}$

V červenci 1945 adresoval ZNV v Praze všem ONV v Čechách další oběžník, kterým cílil na zajištění uměleckých děl z majetku okupantů v obecné rovině. Úřadům se dostalo upozornění, že knihovny je nutné považovat za umělecká díla, nejsou bytovým zařízením a nesmějí být předávány

\footnotetext{
85 Tamtéž, oběžníky datované 1. 7. 1945 byly č. j. Sekretariátu 525-570, 572-598 a 601-625 vypraveny všem ONV v zemi České.

${ }^{86}$ Tamtéž, výnos Sekretariátu adresovaný př́slušnému NV, zde např. č. j. 800 adresovaný Národnímu výboru v Českém Krumlově ze dne 25 . 7.1945.

${ }^{87}$ Tamtéž, č. j. 1135 adresované ZNV, odd. I-6a ze dne 23. 11. 1945. Dokumenty zde uložené v tomto období končí. Z citované zprávy však vyplývá, Že ZNV byla vypravena poslední zpráva o činnosti Sekretariátu do 15. 10. 1945.

${ }^{88}$ Agenda Sekretariátu byla vedena při archivní sekci Kulturní komise a můžeme se i domnívat, že sepětí s archivními kruhy a povědomí o archivních depotech zde převažovalo.

${ }^{89}$ Tamtéž, průběžně - především zprávy tzv. Severočeské zajištovací komise.

${ }^{90}$ Tamtéž, Zpráva o stavu archivu a knihovny v Kačině u Kutné Hory.

91 Tamtéž, č. j. 477, Kačina.

92 Tamtéž, Zpráva gymnaziálního profesora Jana Koupala ze dne 23. 6. 1945.

${ }^{93}$ NA ČR, SPS, kart. 33, dopis MNV v České Kamenici č. j. 140/M/47 ze dne 3. 11. 1947 adresovaný NKK.

${ }^{94}$ ANK, NUK, text výzvy, který byl NUK odeslán 18. 6. 1945 Československému rozhlasu a Československé tiskové kanceláři, aby byl několikrát rozšířen.
} 


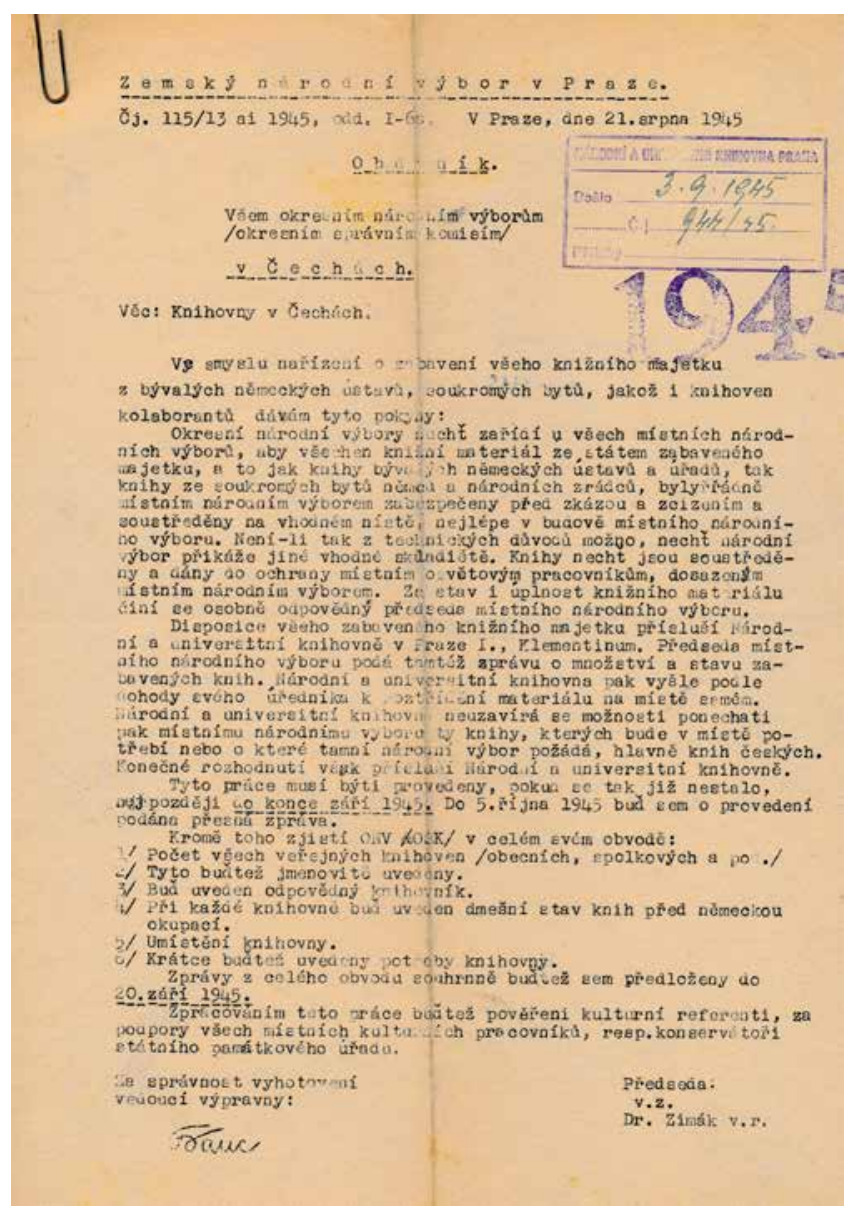

Obr. 3. Oběžník ZNV v Praze ze dne 21. 8. 1945 týkající se zajištování knihoven. Zdroj: ANK, NUK, Zábor.

společně s propůjčeným bytem, ani svévolně odnášeny bez vědomí př́islušných úřadů ${ }^{95} \mathrm{O}$ knihovnách měly informovat Ministerstvo školství a osvěty (dále často jen MŠO) ${ }^{96}-$ i to však žádalo rozhlasem a denním tiskem ONV a MNV už na konci června, aby mu byly hlášeny tyto celky nacházející se v jejich oblasti. ${ }^{97}$ Nejvýznamnější dokument pro podporu činnosti NUK vyšel v srpnu 1945. Jednalo se o pokyn ZNV v Praze, kterým stanovil povinnost MNV zabezpečit pred zkázou a odcizením veškerý knižní materiál, přičemž osobní odpovědnost přenášel na předsedy MNV. Za dispozici s knižním majetkem odpovídala NUK, jež se stala př́ijemcem zpráv o množství a stavu zajištěných knih. K roztřídění materiálu pak měla vysílat svého úředníka prímo na místo. Snad z obav o úspěšnost této akce bylo zmíněno, že „Národní a universitní knihovna neuzavírá se množnosti ponechati pak místnímu národnimu výboru ty knihy, kterých bude v místě potřebí, nebo o které tamní národní výbor požádá, hlavně knih českých. "Zajištění mělo proběhnout do konce záŕí 1945 a zpráva podána ZNV v Praze do 5. ř́ijna. ${ }^{98}$

Dne 22. záŕí 1945 se prvně sešla Komise pro zajištování uměleckých a historických předmětů v zemi České (dále jen Komise). V plénu byly diskutovány zásadní otázky zajišt’ování uměleckých předmětů - hlavní problém členové spatřovali v př́pravě slibovaných zákonných norem, tj. o Národním fondu ${ }^{99}$ a o konfiskaci movitého nepřátelského majetku. Zkonstatováno bylo, že tuto práci nelze vykonávat bez opory $\mathrm{v}$ zákonu, nebot' pouze jím mohla být podpořena autorita všech pověřenců. Vlastní pracovní komise ${ }^{100}$ měla soustředit veškeré informace o doposud shromážděném materiálu od zúčastněných korporací. ${ }^{101}$

Do již tak málo přehledné situace zasáhlo MŠO, které vyvolalo diskusi se ZNV v Praze o další budoucnosti zajišt'ovací praxe. V průběhu října upozornilo, že ,,dosavadní akce [...] se nesetkaly s žádným výsledkem a v mnohých př́padech bylo zjištěno, že jednak knihy i knihovny zůstávají nezajištěny, za druhé, že jsou bez odborného výběru ničeny, nebo odklizovány na mista, kde trpí různými vnějšimi vlivy a konečně, že budovy, mistnosti, vnitřní zařizení i majetkové podstaty knihoven a vědeckých ústavi̊ jsou použivány pro jiné účely, aniž by pri tom byly zajištěny potřebné předpoklady pro zřízení českých knihoven a ústavi̊ v těchto místech. " $102 \mathrm{Z}$ tohoto důvodu vydalo směrnice, aby všechny knihovny dané pod národní správu podle dekretu prezidenta republiky č. 5/1945 Sb. byly příslušnými národními výbory zajištěny a $\mathrm{v}$ případě ohrožení dopraveny na bezpečné místo. Do budoucna neměly být knihy a knižní celky přidělovány soukromým osobám nebo veřejným institucím ani přemistovány, pokud nevyvstala potřeba jejich zajištění. Nejednalo se o žádné novum, nicméně nadále měly odbornou prohlídku knihoven provádět pouze osoby pověřené MŠO ${ }^{103} \mathrm{ZNV}$ v Praze oponoval nutností existence jediného oprávněného subjektu - Komise „pracující ve shodě se státním památkovým úřadem a Národní a universitní knihovnou v Praze ", protože nové směrnice by způsobily u národních výborů ,naprostou

${ }^{95} \mathrm{O}$ zajištěných předmětech měl být sepsán protokol a zaslán do Prahy. Předměty měly být následně svezeny do vhodných a bezpečných skladišt' v obvodu daného ONV.

${ }^{96}$ NA ČR, ZÚ, kart. 802, Oběžník ZNV v Praze č. I-6a-1043/7-1945 ze dne 21. 7. 1945 adresovaný všem ONV k vyrozumění všech př́slušných MNV ve věci Zajištění uměleckých děl z majetku okupantů.

${ }^{97}$ NA ČR, ZÚ, kart. 796, výnos MŠO č. j. B-34.000/451/1 ze dne 28. 6. 1945 ve věci evidence zajištěných knihoven.

${ }^{98}$ ANK, NUK, Oběžník ZNV č. j. 115/13 ai 1945, odd.I-6a ze dne 21. 8. 1945 adresovaný všem okresním národním výborům/okresním správním komisím v Čechách ve věci Knihoven v Čechách.

${ }^{99}$ Pojmem myšlena budoucí NKK.

${ }^{100}$ Plénum komise se skládalo ze zástupců ministerstev, SPÚ, Národní galerie, NM, Uměleckoprůmyslového muzea, Svazu teoretiků a historiků umění, Smetanova muzea, Městského muzea a Sekcí památkové, muzejní, archivní a knihovní ZNV v Praze, vlastní pracovní komise pak ze zástupců Sekce památkové, muzejní, archivní a knihovní ZNV v Praze.

${ }^{101}$ NA ČR, ZÚ, kart. 802, Protokol o ustavení a první poradní schůzi komise pro zajišt’ování uměleckých a historických předmětů v zemi České, konané dne 22. 9. 1945.

${ }^{102}$ NA ČR, ZÚ, kart. 796, výnos MŠO č. B-154.697/45-I/1 ze dne 3. 10. 1945 adresovaný ZNV v Praze ve věci zajištění knih a knihoven z majetku osob státně nespolehlivých.

${ }^{103}$ Tamtéž, výnos MŠO č. B-154.697/45-I/1 ze dne 3. 10. 1945 adresovaný ZNV v Praze ve věci zajištění knih a knihoven z majetku osob státně nespolehlivých. 
desorientaci ke škodě jednotnosti “. ${ }^{104}$ MŠO se nenechalo odbýt a argumentovalo rozsáhlostí a náročností prací spojených se zajišt’ováním knižního materiálu, na něž dle jeho dosavadních zkušeností Komise ani NUK nestačily, a proto by uvítalo jejich spolupráci s dalšími jím pověřenými orgány. Svou oprávněnost $\mathrm{v}$ dané věci podpořilo i požadavkem, aby mu byla sdělena jména členů Komise, kterým chtělo vydat vlastní pověření. ${ }^{105} \mathrm{~V}$ únoru následujícího roku se do diskuse zapojila i NUK, z jejíhož dopisu ZNV v Praze bylo patrné roztrpčení nad celou situací. Knihovna konstatovala, že vždy spolupracovala se všemi pověřenými orgány a zároveň apelovala na vydání směrnic s jednoznačně vytyčenými kompetencemi v záboru dosud zainteresovaných složek. Nakonec upozornila i na skutečnost, že její pověření konfiskací všeho státem zabaveného knižního majetku nebylo ZNV v Praze ani nikým dalším odvoláno. ${ }^{106}$ Jakým způsobem zasáhla do zajišt'ovací praxe Komise není zřejmé, budeme se domnívat, že těsnou hranici spolupráce mezí ní a původně pověřenými orgány nelze oddělit. Víme však, že NUK stihla do konce roku 1945 převzít knihy z téměř sedmi set míst, z čehož 520 z nich se nacházelo na území Prahy. Při přebírání knihoven narazila především na nedostatek místa $\mathrm{v}$ Klementinu: ,,zabaveného materiálu je na venkově tolik, že by na něj nebylo v NUK mista a že by také jej nebylo lze do Prahy dopraviti, z toho důvodu jsou MNV žádány, aby pokud možno zasilaly NUK seznamy těchto zabavených knih a knihy samé ponechávaly zatím v bezpečném zajištěni na mistě, nebo je zaslaly do NUK poštou nebo vlakem. "Tímto způsobem stihla do konce roku vyřídit 1540 prrípadů. ${ }^{107}$

Rozepře mezi zainteresovanými úřady se stala ale takřka okamžitě minulostí vydáním dekretu prezidenta republiky č. 108/1945 Sb. (viz výše) a vznikem FNO odpovědnými za správu movitého majetku. Dosavadní zajišt’ovací praxe tak vzala, alespoň ,„papírově“, za své. Ministerstvo žádalo již v listopadu 1945, aby při přípravě návrhů zvláštních vládních nařízení byl vzat v úvahu jako zvláštní druh konfiskátů knižní materiál a aby jeho ,,posouzením, odhadem i distribucí“ pověřila právě MŠO, které by společně se ZNV rozhodlo o nejvhodnějším zužitkování tohoto majetku, na svůj výnos však přes veškeré urgence nedostalo žádnou odpověd'. V průběhu roku 1946 byly svolány meziministerské porady, kterými měly být vyjasněny kompetence jednotlivých úřadů a ústavů ve věci zajišstování a distribuce knih a vydání směrnic $\mathrm{k}$ těmto úkolům. FNO si v těchto jednáních vymínil výhradní kompetence a připravil pokyny pro ONV, směrnice i normy $\mathrm{k}$ př́idělovému řízení tisků, $\mathrm{k}$ jejichž vydání úřední cestou ale nedošlo. ${ }^{108}$ V květnu 1946 byl nadto vydán zákon o zrízení NKK, ${ }^{109}$ jíž měly $\mathrm{v}$ budoucnu připadnout úkoly týkající se správy kulturního a vědeckého majetku, činnost však začala vyvíjet až v následujícím roce.

FNO byl ustanoven v březnu $1946^{110}$ a zjednodušeně řečeno se jeho hlavním úkolem stalo urychlené přerozdělení a finanční zhodnocení majetku. Předpokládáme, že na nátlak zapojených úřadů byly jeho směrnicemi vyňaty předměty kulturní hodnoty z prímého odprodeje, které měly být do konečného rozhodnutí uskladněny $\mathrm{v}$ jeho příslušných skladištích. ${ }^{11} \mathrm{~K}$ odprodeji knižního materiálu z těchto skladišt' vypsal FNO v únoru 1947 ofertní řízení, na což MŠO zareagovalo pověřením úřredníků (knihovníků) univerzitních a vědeckých knihoven $\mathrm{k}$ přítomnosti při jejich třídění, materiál nesměl být prodán en bloc. ${ }^{112}$ Pro výběr knih byly stanoveny následující zásady: ,,1) z odprodeje je vyloučena a bude proto vytříděna veškerá literatura neněmecká, 2) všechny tisky, které svým obsahem nebo pưvodem se týkají, nebo mají význam pro Československo, kromě čistě zábavné beletrie německých autorů pocházejících z Československa, 3) staré tisky, pokud mají význam bud' svým obsahem nebo tiskařským provedením. Zde je zvláště pozornost věnovati tiski̊m pocházejícím z tiskáren československých, 4) všechny tisky bibliofilské, vzácné, čislované výtisky bohatě ilustrované knihy a knihy, jež jsou opatřeny věnováním autora, pokud jde ovšem o autora skutečně významného, 5) úplná a vzácná vydání, zejména komentovaná, sebraných spisủ klasických autorio, 6) místni vlastivědná literatura, která budiž ponechána $v$ nejbližši vhodné mistní knihovně, 7) hodnotná moderní vědecká literatura všech oborů, zejména moderní, nikoliv však populárni a popularisující. Ze starši vědecké literatury ta díla, u nichž je pravděpodobnost, že nejsou v našich knihovnách v dostatečném počtu zastoupena, 8) úplnější výběr německé vědecké literatury je požadován pro válečnou dobu, t. j. od r. 1939 až do r. 1945, nebot' tyto knihy nejsou zastoupeny $v$ knihovnách anglo-amerických a jeví o ně zájem zejména UNESCO, 9) hudebniny nutno pojmouti do výběru v nejširšsi míre, zejména hudbou klasickou a $k$ odprodeji možno ponechati dalši exempláře běžné hudební literatury, pokud se vyskytuji $v$ celých nákladech a lehkou a tanečni hudbu, 10) tisk slepecký, mapy a litografie jsou z prodeje vi̊bec vyloučeny. "113 Při probírce skladišt' se úředníci měli omezit na díla ,,nejhodnotnějši a potřebná, při čemž rozhodující musí býti zásada, že z Československa nesmí býti vyvezeno nic, co by snad bylo nutno později pro naše knihovny draze kupovati ".114 Samotný postup trrídění vypadal zhruba takto - knihovníci vyjížděli na místo a po probírce nechali odeslat vybrané tituly (zpravidla) do své domovské instituce a hlášení o akci zasílali

\footnotetext{
104 Tamtéž, koncept dopisu ZNV v Praze č. 115/83-1945, odd. I-6a adresovaný MŠO

105 Tamtéž, Dopis MŠO č. B-1616.963/45-I/1 ze dne 19.12. 1945 adresovaný ZNV v Praze ve věci zajišt’ování knih.

106 Tamtéž, dopis NUK č. j. 218/46 ze dne 12. 2. 1946 adresovaný ZNV v Praze.

${ }^{107}$ ANK, VZ, výroční zpráva za rok 1945, s. 22; hlášenky o zajištění knihy a informace o zaslaných knihách srov. NA ČR, ZÚ, kart. 796 průběžně.

${ }^{108}$ NA ČR, MS̆K, kart. 2008, Spis MŠO č. j. B-203099/46-I/1 ve věci likvidace německých knih a knihoven datovaný 31. 10.1946.

109 Zák. č. 137/1946 Sb.

110 Srov. vl. nař. č. 45/1946 Sb. FNO podléhaly osidlovacímu úřadu, při kterém byly zř́zeny, předsedu jmenovala vláda na návrh ministra vnitra. Př́islušela mu veškerá agenda v zajištění majetku konfiskovaného podle dekretu č. 108/1945 Sb., tedy správa a rozdělení.

111 Vyhl. č. 1213/46 Ú. 1.; Vyhl. č. 2141/46 Ú. 1.; Vyhl. č. 2142/46 Ú. 1.

112 NA ČR, MŠK, kart. 1973, Spis MŠO č. j. B-98475/1947-I/1 ve věci německých zkonfiskovaných knih datovaný 30. 4.1947.

${ }^{113}$ NA ČR, MŠK, kart. 1973. Výnos MŠO č. B-98.475/47-I/1 ze dne 30. 4. 1947 - Směrnice, podle kterých jest postupovati při vytřid’ování knih z německých konfiskátů.

114 Tamtéž, Spis MŠO č. j. 98475/1947-I/1 ve věci německých zkonfiskovaných knih datovaný 30. 4. 1947.
} 

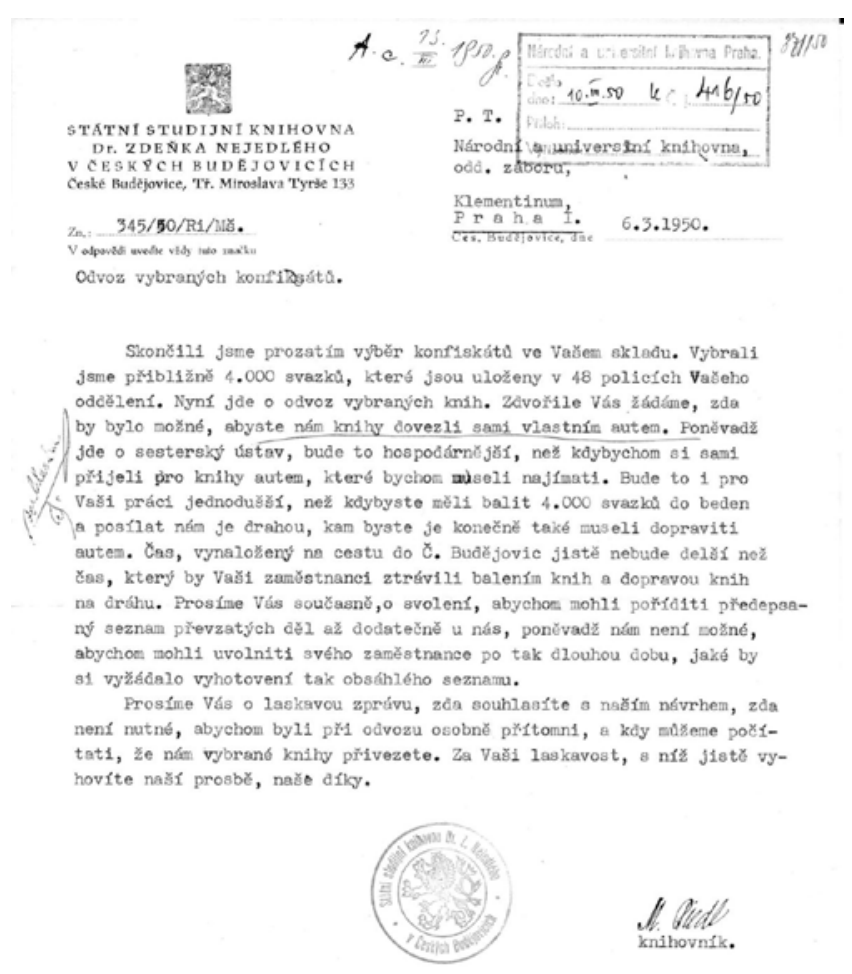

Obr. 4. Státní studijní knihovna v Českých Budějovicích informuje NUK o výběru z jejích konfiskátů. Zdroj: ANK, NUK, Zábor.

MŠO. Zapojili se především knihovníci NUK, ZUK, Studijní knihovny v Liberci a Universitní knihovny v Olomouci. Následně byly knihy znovu tříděny prímo v knihovnách podle oborů a o jejich př́děl se hlásily další vědecké, universitní či administrativní knihovny. Ze zpráv NUK je patrné, že se s konfiskáty vypořádávala ještě na počátku 50 . let. ${ }^{115}$
Praxe se př́liš nezměnila ani po zahájení činnosti NKK v roce 1947 (viz níže), pričcemž součinnost byla výrazně zpožděna průtahy vzniklými vyjednáváním dohody o spolupráci s FNO. Její návrh sice NKK zaslala již v květnu 1947, podepsána byla však až v dubnu $1949 .{ }^{116} \mathrm{~V}$ mezičase požádala NKK, aby jí FNO poskytl seznam skladišt' a sběren k provedení vytř́ídění státního kulturního majetku. FNO též souhlasil s tím, aby se důvěrníci NKK moli účastnit prodejních řízení v roli pozorovatelů s právem zajistit kulturně cenné předměty za předpokladu, že neohrozí jejich plynulý chod. ${ }^{117}$ Abychom si vytvořili představu o počtu zajištěných a trríděných knih: do konce roku 1946 bylo do Klementina svezeno více jak 800 tisíc svazků, ${ }^{118}$ v knižních skladištích prohlédli knihovníci NUK do ř́jna 1949 na 12 milionů knih. ${ }^{119}$

Oproti knihám konfiskovaným podle dekretu prezidenta republiky č. 108/1945 Sb. byla správa skupiny knih, které se nacházely na sídlech spjatých se zemědělskou půdou, výrazně jednodušší. $Z$ legislativního hlediska byla dekretem prezidenta republiky č. 12/1945 Sb. zabrána zemědělská půda, s níž souvisela většina šlechtických sídel historicky tvořících nedílnou součást velkostatkủ, byt' výrazně okleštěných první pozemkovou reformou (viz výše). ${ }^{120}$ Veškeré kompetence $\mathrm{v}$ nakládání $\mathrm{s}$ tímto majetkem byly dány Národnímu pozemkovému fondu při ministerstvu zemědělství (dále jen často NPF), jenž byl zř́zen týmž dekretem. ${ }^{121}$ Zajištěný majetek spravoval až do jeho předání novým príidělcům, o kterých rozhodovalo MZe samostatně, panovala však shoda, že neměly být předávány soukromým žadatelům.

Prováděcí směrnice dekretu nebrala zpočátku $\mathrm{v}$ úvahu památkovou hodnotu objektů a jejich inventáře, taktéž se různil př́stup národních správcù (jmenovaných ZNV v Praze) ke svěřenému majetku. V červenci 1945 vyhovělo MZe požadavku MŠO ${ }^{122}$ a zř́dilo při ministerstvu poradní orgán, který měl dohližet na zohlednění ochrany památkových hodnot konfiskovaných objektů a jejich zařízení. Tato Památková komise ${ }^{123}$ zahájila svou činnost v srpnu 1945 a složena byla ze zástupců MZe, MŠO, Státního archivu zemědělského, NPF, Státních lesů a statků a Státního

${ }^{115}$ Srov. např. ANK, NUK, Zábor, kart. B3/6, průběžně.

116 ÚDU AV ČR, OD, NKK, kart. VIII, Dohoda o spolupráci Národní kulturní komise při přejímání státního kulturního majetku ze dne 4. 4. 1949. V zásadě se př́liš nelišila od stávající praxe s pověřenci MŠO/MŠVU. Výběru se měli účastnit zástupce NKK i FNO a o předmětech rozhodnout jednomyslně.

${ }^{117}$ Při prodeji tato praxe neprobíhala hladce, v některých sběrnách byli zástupci FNO př́ítomností zástupců NKK zaskočeni, srov. NA ČR, SPS, kart. 19, Dopis NKK č. j. 655/1948 ze dne 4. 2. 1948 adresovaný FNO ve věci dohody o spolupráci.

${ }^{118}$ NA ČR, MŠK, kart. 594, Program Národní a universitní knihovny v dvouletém plánu, dobudování organisace ústavu.

${ }^{119}$ Tamtéž, NUK, Zpráva oddělení záboru č. j. 4351/49 ze dne 2. 11. 1949 adresovaná MŠVU. Informace o počtech prohlédnutých knih jinými institucemi nejsou zahrnuty pro nedostatek pramenů.

${ }^{120}$ UHLÍKOVÁ 2019, s. 89.

${ }^{121}$ Srov. vl. nař. č. $70 / 1945 \mathrm{Sb}$., podle $\S 1$ byl podřizen ministerstvu zemědělství, zastupován předsedou jmenovaným vládou na návrh ministra zemědělství.

${ }^{122}$ NA ČR, MŠK, kart. 2008, opis MŠO č. j. 151.234/45 ze dne 13. 7. 1945 adresovaný MZe ve věci kulturních úkolů souvisejících s dekretem prezidenta republiky o konfiskaci zemědělského majetku z 21. 6. 1945. Podle konceptu se na tomto komentári významnou měrou podílel $\mathrm{Z}$. Wirth v roli poradce MŠO. Základním požadavkem bylo, aby došlo k definitivnímu programu pro př́děl těchto objektů a jejich inventáře. Poukázáno bylo dále na to, že tyto aspekty nebyly zohledněny při provádění první pozemkové reformy. Návrh počítal se sestavením odborné komise složené z uměleckého historika, dvou muzejníků, archiváře a knihovníka. Dojít mělo ke klasifikaci předmětů na rodinné památky, galerijní a muzejní objekty, archivy, knihovny, grafické soubory ad., interiérové soupravy a užitkový mobiliár. Základní požadavek ovšem zněl, aby došlo k definitivnímu programu pro užití těchto objektů a jejich inventářù, protože při první pozemkové reformě nebylo vinou zúčastněných činitelů a pro jejich odpor provedeno řádné roztřídění a účelové přidělení stavebních objektů.

${ }^{123}$ MŠO jmenovalo do komise jako své zástupce Zdeňka Wirtha, Jana Morávka, Rudolfa Maximoviče, MZe zastupovali vedoucí pracovníci Státního zemědělského archivu, ředitel Václav Černý a jeho zástupce Emanuel Janoušek, za IX. odbor MZe se schůzí účastnil Jindřich Pravenec. Po zřízení NPF se ke komisi připojil i vedoucí památkového referátu této instituce Jaromír Soukup. Prakticky stejné personální obsazení se později dotklo i NKK. K Památkové komisi více UHLÍKOVÁ 2004, s. 24. 
plánovacího úřadu. Komise posuzovala vhodnost využití objektů podle návrhů uchazečů a dohlížela ve spolupráci s památkovým referátem $\mathrm{NPF}^{124}$ na jejich řádnou správu. Většina z nich disponovala množstvím umělecky hodnotných předmětů, které neměly být předány jako součást nemovitostí a bylo nutné je vyjmout z přídělového řízení. U zámků, kde bylo předání objektu novému vlastníkovi bezodkladné, prováděli členové výběr umělecky nejcennějšího mobiliáře, ne vždy se ovšem podařilo tento postup dodržet a budovy byly předány včetně takových předmětů: ${ }^{125}$ „Není možno vždy najednou zpracovati všechny objekty $v$ jednom správním okrese, poněvadž vzhledem $k$ intervencím a různému naléhání nutno zpracovávati bezprostředně za sebou objekty od sebe na stovky kilometrů vzdálené. Jest to konečně pochopitelno, poněvadž každý z uchazečù se domnívá, že jeho nároky jsou nejpřednější, jeho di̊vody nejpodstatnější, právě že jeho prripad musí býti vyšetřen přede všemi jinými. Je to prostě lidské a někdy, priznejme, i odưvodněné. "126

Krátce po zahájení činnosti sestavila Památková komise Směrnice pro národni správce hradi̊ a zámki̊ na zkonfiskovaném zemédělském majetku. ${ }^{127}$ Stav jednotlivých objektů se při návštěvě komise výrazně lišil, v četných př́padech sloužily krátce po osvobození jako útočiště vojenských posádek, jako např. v př́ípadě výše zmíněné Kačiny. Obecně byly a jsou ohromné kulturní ztráty, poničení a vybydlení jednotlivých objektů přičítány Rudé armádě. J. Soukup však ve své zprávě o zajišt'ování objektů odhadoval, že $75 \%$ poškození kladených za vinu vojákům naopak padalo na vrub čs. obyvatelstva: „Poplenili-li nějaký takový objekt války nebo postupujici vojenské útvary, nutno se s tím, třeba s lítostí smírit. Tomu konečně rozumíme a to chápeme. Ale nerozumíme v žádném př́padě tomu, když naši lidé vrhli se na tyto objekty a roznášeli jejich zařizení, když některé okresni národni výbory, a zaplat' pán bi̊h, že jich nebylo mnoho, začaly zařizení zámecké rozprodávat (Železný Brod) nebo rozebrali celý zámek, jako to udělal ONV v Čáslavi se zámkem v Golčově Jeníkově, a rozpưjčili zámecké zařizeni do uživáni soukromníkům, ba dokonce zemskému poslanci. Když pak prišel úředník NPF toto zařizeni shledávat a sepisovat, prostě jej vyhnali. " 128 NPF v této první fázi vyčlenil 50 zámků a určil je za objekty I. kategorie ${ }^{129}$ - později měly být předány do správy NKK. Poměrně jasné představy a praxe fungovaly pro movité umělecké předměty, jakými byly obrazy, sochy, nábytek, porcelán - ty se odevzdávaly Národní galerii a Uměleckoprůmyslovému muzeu jako státní depot. Obrazy a rodinná korespondence se soustřed'ovaly $\mathrm{k}$ budoucímu užití na některém z objektů I. kategorie. V př́ipadě zbraní, paroží a loveckých trofejí se plánovalo jejich předání odborným muzeím a školním kabinetům. S majetkem výše neuvedeným se počítalo pro reprezentativní účely státních sídel.

Samostatnou kapitolou zůstávala otázka zámeckých knihoven. Jednalo se co do počtu o velké celky, zabírající na jednotlivých sídlech i více místností. „, Bylo období, $k d y$ velmi pečlivě shromažd'ovala se současná literatura a sbíraly se staré tisky a rukopisy. Leč tento zájem brzy ustoupil jiným zálibám, misto kultury byly to koničky, karty a jiné zábavy pro ukrácení chvile a o posledních dvou až třech generacích šlechtických rodů možno, až na skromné výjim$k y$, ř́ci, že neměly vůbec zájem na doplňování knihoven, a když, tedy zcela plytkou literaturou. Po stránce jazykové najdete tu Babylon světových řeči, český knižní materiál našli jsme prì prohlídce dosud 200 zámeckých objektů jedině na Manětíně. “ J. Soukup uvedl, že krátce po osvobození zasáhly v této věci NUK, Národní muzeum i Náprstkovo muzeum a část zámeckých knihoven umístily ve svých budovách. Plán počítal s instalací významných celků v zámcích I. kategorie, ostatní měly být svezeny $\mathrm{k}$ výběru hodnotného materiálu pro vědecké ústavy. ${ }^{130}$

Přestože zajišt'ování objektů kulturní hodnoty bylo uskutečňováno uvedenými subjekty kontinuálně od konce války, cesta k vydání zákonné normy a zř́zení samostatného

\footnotetext{
${ }^{124}$ Památkový referát byl při NPF zrŕzen 21. 8. 1945 - srov. Zpráva J. Soukupa o zajištování konfiskovaných hradů a zámků NPF, publikováno v UHLÍKOVÁ 2004, dokument II/4.3., dále jen Zpráva J. Soukupa.

${ }^{125}$ UHLÍKOVÁ 2004, s. 24-25. V letech 1945-1947 prohlédla Památková komise 185 objektů.

${ }^{126}$ Zpráva J. Soukupa.

127 Národní správce sestavoval z důvěryhodných osob komisi, jejímž úkolem bylo neprodleně pořídit soupis inventáre. V něm měly být zahrnuty i předměty, které byly z majetku objektu zapůjčeny dalším osobám nebo úřadům, ze zámku odneseny, případně které se dostaly jiným způsobem do cizích rukou. Památkově a umělecky hodnotné předměty včetně knihoven, bylo nutné přemístit do dobře zajiššené místnosti (opatřené zabezpečovacími páskami, dostatečně větrané) a dále učinit veškerá opatření, aby tyto předměty nepodléhaly zkáze. Srov. nedatovaná Směrnice pro národní správce hradů a zámků na zkonfiskovaném zemědělském majetku, publikováno v UHLIKOVÁ 2004, dokument II/4.4.

${ }_{128}$ Zpráva J. Soukupa.

${ }^{129}$ Tj. objekty ponechané ve vlastní správě pro další výlučně kulturní využití. Srov. UHLÍKOVÁ 2004, s. 24.

${ }^{130}$ Srov. zpráva J. Soukupa. Prohlídky knihoven se účastnil zřejmě i B. Lifka, který o jejich stavu podával zprávy NUK, která je předávala MŠO, neni ovšem patrné, z jaké pozice - srov. nap̌r. NA ČR, MŠK, kart. 594 průběžně.
} 
orgánu byla ještě poměrně dlouhá. ${ }^{131}$ Zákon o NKK sice vešel v platnost v květnu 1946, ${ }^{132}$ samotná činnost byla zahájena až v únoru 1947, ${ }^{133}$ ukončena potom na konci roku 1951. ${ }^{134}$ Podle zákona jí příslušela správa a využití ,, majetku všech druhů, movitého i nemovitého, bez rozdilu doby vzniku, který měl kulturní (uměleckou, historickou, vědeckou) hodnotu kteréhokoli stupně “, konfiskovaného podle dekretů prezidenta republiky č. 12/1945 Sb. a č. 108/1945 Sb. a nařízením Slovenské národní rady ze dne 23. srpna 1945 č. 104 Sb. nař. SNR, o konfiskování a urychleném rozdělení zemédělského majetku Němců, Mad'arů, jakož i zrádců a neprátel slovenského národa. Stejně tak spravovala ostatní státní kulturní majetek, ${ }^{135}$ přičemž se jednalo o: a) pozemky, které měly charakter prŕrodní památky, rezervace nebo archeologické lokality, b) stavební objekty umělecké nebo historické hodnoty i pozemky památkového charakteru a c) movité věci hodnoty umělecké, historické nebo vědecké. Za úkol měla tento majetek zjišt'ovat, přebírat do vlastní správy a zároveň organizovat obecně odbornou správu kulturního majetku, pečovat o jeho vhodné využití, př́ípadně uskutečňovat jeho prodej za souhlasu ministrů školství a financí. ${ }^{136}$ Významnou pravomocí bylo svěřování správy nebo dozor nad ním odborným korporacím, ústavům nebo jednotlivým odborníkům. ${ }^{137}$ Předseda komisi zastupoval navenek a prováděl její usnesení. NKK měla navrhovat MŠO předměty pro určení za státní kulturní majetek, vydávat směrnice pro „zjištění, sběr, třídění, konzervaci, přidělení a využití státního kulturního majetku“, stanovit programy pro jednotlivé roky ad. ${ }^{138}$ Pro zdárné přejímání objektů a předmětů podle zákona č. 137/1946 Sb. byla uzavřena v dubnu 1947 dohoda mezi NKK a NPF o spolupráci při přejímání a likvidaci majetku. Touto dohodou byla zakotvena již zažitá praxe: ,Oba činitelé přistupuji $k$ dohodě o uprrimné spolupráci po více než roční zkušenosti, ziskané spolučinnosti Památkové komise při ministerstvu zemédělství, kulturního sektoru ministerstva školství a památkového referátu NPF. " "139 V zásadě platil pro přejímání následující postup: vytříděn byl majetek hodnoty umělecké, historické nebo vědecké, převzatý pro vybavení objektů I. kategorie i pro „obohacení“ veřejných muzejních sbírek, knihoven a archivů a ostatní majetek, ponechaný k zužitkování prostřednictvím NPF. ${ }^{140}$

Specifikum knihoven ze zámeckých objektů pramenilo především z toho, že je nebylo možné okamžitě zachytit soupisem, noví nabyvatelé zámků tlačili na jejich vyklizení, NKK však nedisponovala dostatkem pracovních sil, pročež bylo rozhodnuto přjímat knihovny jako celky. ${ }^{141}$ Svoz

${ }^{131}$ Už od roku 1945 se objevovaly snahy o zřízení orgánu či fondu, který by měl kulturní majetek na starost. Aktivní roli sehrál prezident Edvard Beneš, jenž informoval předsedu vlády Zdeňka Fierlingera o svém př́ní, aby pro správu kulturního majetku vznikl zvláštní fond. V průběhu jednání se o prrípravy nadále aktivně zajímal, nicméně projednávání v rámci zúčastněných resortů se protáhla a nebylo tak docíleno toho, aby norma vyšla ještě v podobě dekretu prezidenta republiky. Srov. UHLÍKOVÁ 2004, s. 29.

${ }^{132} \mathrm{~V}$ důvodové zprávě k zákonu bylo konstatováno následující: „Bohužel utrpěl již tento majetek překotnými zásahy nejrůznějšich činiteli̊, a to jak státnich resorti̊, národnich rad, veřejných i soukromých korporací; tak neukázněných jednotlivců značné ztráty přesunováním, zcizováním, ba nerozumným ničením kulturních předmětů. Současněs těmito zásahy neoprávněných činitelü domácích utrpěl konfiskovaný majetek kulturní pronikavé škody zásahy vojenských oddilů na československém území přechodně ubytovaných, čimž byly některé významné stavební objekty úplně zbaveny svého kulturního inventáře. Tyto nezdravé zjevy nelze paralysovati než rychlou evidencí všech kulturních statků a věcí do citovaných dekretů zahrnutých, jejich odborným zajištěním a roztřiděním, udržováním v řádném stavu a cílevědomým kulturním využitím. Při tom nerozhoduje, jde-li majetek nashromážděný organickým vývojem nebo sběratelskou činností jednotlivců v různých obdobích, o stylové originály nebo jejich kopie, nebo dokonce falsa, bona i mala fide. "Srov. Internetový portál Společná česko-slovenská digitální parlamentní knihovna - důvodová zpráva k zákonu č. 137/1946 Sb. o NKK, Tisk NS T.344. Dostupné z: https://www.psp.cz/eknih/1945pns/tisky/t0344_00.htm [cit. 1.12.2020]; UHLÍKOVÁ 2004, s. 29. Statut NKK byl dán vyhl. MŠO č. 125.

${ }^{133}$ Ustavující schůze NKK se konala 18. 2. 1947. NKK byla podle §1-2 zřízena při MŠO (na Slovensku při pověřenectvu školství a osvěty) jako poradní sbory ministra (pověřence) školství věd a umění, jejich členy jmenovala a odvolávala vláda (sbor pověřenců). Komise se skládaly ze zástupců ministerstev školství a osvěty, vnitra, financí, zemědělství, dopravy, vnitřního obchodu, Státního úřadu plánovacího a ministerstva národní obrany, na Slovensku ze zástupců př́slušných pověřenectev, Plánovacího úřadu a ministerstva národní obrany, další členové byli jmenováni ministrem školství a osvěty z odborných znalců př́íslušných oborů.

${ }^{134}$ Správa hradů a zámků přešla částečně přímo pod MŠVU, částečně pod referáty pro školství, osvětu a tělesnou výchovu př́íslušných KNV. Model se ukázal jako dysfunkční a v polovině roku 1953 byla zrrízena jednotná centrální instituce - Státní památková správa, která sloučila všechny orgány státní památkové péče. Svou činnost pak zahájila plošnou revizi a reinventarizací majetku. Na základě ustanovení zákona č. 22/1958 Sb. o kulturních památkách byl v roce 1959 zahájen proces decentralizace památkové péče a většina agendy Státní památkové správy měla být přenesena na krajská střediska státní památkové péče a ochrany př́rody, která jako svůj výkonná orgán zřizovaly KNV. Přenos agend byl záležitostí dlouhodobou a pro toto období operovala Státní památková správa v likvidaci. Dále byla využita koordinační komise pro kulturní využití státních hradů a zámků coby poradní orgán MŠVU, zastoupení v ní měly Státní ústav památkové péče a ochrany př́rody, Národní galerie, Uměleckoprůmyslové muzeum, NM a zmíněná Státní památková správa v likvidaci - více k problematice UHLÍKOVÁ 2019, s. 110-114.

135 \& 2 zák. č. 137/1946 Sb.

136 Tamtéž, § 3, odst. 1.

${ }^{137}$ Tamtéž, § 4. Orgány, úřady a osoby, které měly ve své správě majetek prohlášený za státní kulturní, byly povinny jej odevzdat NKK na jejich žádost. Pakliže již byl tento majetek předán třetím osobám, měly se postarat o to, aby byly tyto věci neprodleně odevzdány NKK a pokud to nebylo možné, aby to bylo NKK oznámeno - viz tamtéž § 6. Organizačním řádem bylo stanoveno složení komise - v jejím čele stál předseda, kterého jmenoval a odvolával ministr školství a osvěty, dále byla složena ze zástupců daných zákonem (srov. pozn. 135), z jejich řad měl být jmenován místopředseda. Jako znalci byli po jednom jmenováni odborníci pro ochranu př́rody, archivnictví a knihovnictví, pro obor působnosti FNO a NPF a tři znalci z oboru muzejnictví. Srov. vyhl. MŠO č. 125. Členové komise byli jmenováni v únoru 1947. Srov. VĚSTNÍK MINISTERSTVA ŠKOLSTVÍ A OSVĚTY 1947.

${ }^{138}$ Finanční prostředky pro její chod měly ze svých rozpočtů vyčlenit MŠO a Ministerstvo techniky. K provedení jejích úkolů mělo MŠO vyčlenit administrativní kancelář, potřebné sběrny, skladiště a dílny, Ministerstvo techniky potom zřídit technickou kancelář k udržování stavebních objektů. Srov. UHLÍKOVÁ 2004, s. 31-34.

${ }^{139}$ NA ČR, SPS, kart. 19, Dohoda o spolupráci Národní kulturní komise (NKK) a Národního pozemkového fondu (NPF) při přejímání a likvidaci zkonfiskovaného majetku podle dekr. č. 12/1945 Sb. O tom, že správa majetku konfiskovaného podle dekr. č. 12/1945 Sb. měla o dost hladší průběh, než movitostí podle všeobecného konfiskačního zákona svědčí to, že dohoda s FNO byla uzavřena o poznání později - srov. výše.

140 Tamtéž.

${ }^{141}$ NA ČR, SPS, kart. 34, Zápis z porady o německých publikacích, konané dne 28. 5. 1949. 
knihoven a jejich výběr ze zámeckých objektů měl ve své kompetenci knižní referent Václav Chaloupka, jenž je velmi hrubě vytřídil na místě, bohemikální literaturu ponechal většinou osvětovým potřebám místních institucí, případně určil pro prodej. ${ }^{142}$ Odborná a cizojazyčná literatura byla svážena zpravidla do nejbližších zámeckých objektů ve správě NKK, př́ípadně do některé $\mathrm{z}$ jejích sběren, prǐčemž $\mathrm{k} 1$. prosinci 1949 disponovala komise 43 takovými objekty. ${ }^{143}$ Abychom si představili rozsah činností NKK či jejích pokračovatelů je nutné si uvědomit, že do správy státu bylo převedeno: 462 zámků podle dekretu č. 12/45 Sb., 298 podle zákona č. 142/47 Sb. a 43 dalších, dohromady tedy 803 objektů. Do konce činnosti NKK byla $\mathrm{v}$ dobové terminologii eliminována pouze větší polovina těchto objektů, z nichž velká část disponovala zámeckou knihovnou. ${ }^{144} \mathrm{Ne}$ vždy proběhlo vše hladce, o čemž věděl $\mathrm{V}$. Chaloupka své. Bylo napřs. dohodnuto, že převezme knihovnu z Krásného Března, ale orgány MNV mu byl znemožněn př́stup do objektu: „Převážení knihovny nepokládáme za nutné, protože tř́děni knih, jež je důvodem $k$ prevozu může být provedeno v mistě uskladněni a roztřiděné knihy mohou být ref. IV JNV [jednotný národní výbor] dopraveny do knihoven $v$ okrese nebo kraji Ústí n. L. př́mo. Tento postup pokládáme za správnějši a úspornějšsi nežli jízdy a nenadálé návštévy s. Chaloupky, prípadnè nenadálé akce, na něž referát nebyl predem upozorněn, jež nemá zatím v plánu a s nimiž proto nemũže souhlasit. Současně projevujeme názor, že s. Chaloupka by mohl býti lépe a hospodárněji využit, kdyby jeho práce byla lépe plánována. " 145

Blíže nespecifikovaný počet zámeckých knihoven byl prìdělen v letech 1945-1946 NUK a ZUK, o převzatých knihovnách však nejsme blíže zpraveni. ${ }^{146}$ Později byla tato praxe kritizována, NKK totiž nebyla o převzatých celcích informována, čímž uvedené instituce obešly zákon o NKK. $Z$ tohoto důvodu jim nadále nebyly svěřovány $\mathrm{k}$ vytrrídění. ${ }^{147}$

Výnosem MŠVU z dubna 1950 vznikla komise, která měla rozhodnout o pořadí žadatelů o vytř́íděný knižní materiál. Jejím předsedou byl jmenován Z. Wirth, který se výraznou měrou podílel na třídění knih uložených ve sběrnách NKK. ${ }^{148}$ Mezi dalšími členy figurovali knižní referent NKK F. Chaloupka, za MŠVU V. Vaněček a J. Drtina, dále pak ředitel Univerzitní knihovny v Olomouci S. Křupka, za NUK K. Groh a za Náprstkovo muzeum B. Lifka. Na vlastní činnost této komise již nedošlo pro nedostatek pracovních sil, z dostupných pramenů vyplývá, že spolupráci přislíbila Státní knihovnická škola, ale dohoda s ní padla.

Tř́idění dále vykonávala NKK sama pro instituce, jakými byly Technické muzeum, Národní muzeum, Náprstkovo muzeum, Národní galerie nebo Hipologické muzeum ve Slatiňanech, přičemž tímto způsobem bylo vytříděno 170 knihovních celků. Např. ve sběrně na zámku Sychrov byly koncentrovány knihy ze zámeckých objektů, ale i německých bytů (konfiskáty podle dekretu č. 108/1945 Sb.). Tř́dilo se do 37 oborů a do roku 1953 došlo ke zpracování 170000 svazkủ. ${ }^{149} \mathrm{~V}$ roce 1953 disponovala Státní památková správa 51 sběrnami, kde se nacházelo 314 knižních svozů, ${ }^{150} \mathrm{z}$ nich bylo do roku 1953 pro vědecké účely vytříděno čtvrt milionu svazků. ${ }^{151}$ Př̆i likvidaci svozových knihoven mělo být pamatováno vědeckou literaturou především na ústavy Československé akademie věd, v druhé řadě na odborné ústavy a muzea, a to literaturou, jejíž vědní obory nebyly dosud v ČSAV zastoupeny a nakonec na univerzitní a studijní knihovny a to též tituly, které dosud nebyly $\mathrm{v}$ jejich fondech zastoupeny. ${ }^{152}$

V červnu 1954 byla výnosem ministerstva školství a kultury pověřena Knihovna Národního muzea převzetím a odbornou správou hradních a zámeckých knihoven. Vypracovat měla centrální katalog a tím tyto fondy všeobecně zpř́stupnit. Toto ustanovení nebylo změněno ani po zrušení Státní památkové správy, kdy byly dalším výnosem ministerstva školství v roce 1959 převedeny instalované zámecké knihovny do majetku KNV, př́padně národních výborů nižších stupňů. ${ }^{153}$ Svozové knihovny byly trííděny ještě počátkem 70. let a jejich historická jádra postupně převážena do předem určených depozitářů na zámcích I. památkové kategorie, $\mathrm{k}$ soustředění ostatní literatury vznikla dvě distribuční střediska - na hradě Křivoklátu a ve Žd'áru nad Sázavou, odkud byla nabízena dalším knihovnám a ústavům, př́padně pro prodej Antikvariátu, n. p. ${ }^{154}$ Můžeme tedy konstatovat, že trend nastavený činností NPF a NKK pokračoval i nadále.

\section{Závěr}

Nakládání s knižním majetkem postihl v letech 1918 až 1954 bouřlivý vývoj kopírující politické události. V období první republiky byly ve vztahu k majetkovým přesunům zcela určující procesy související s prováděním první pozemkové

\footnotetext{
${ }^{142}$ NA ČR, SPS, kart. 57, Zápis o VIII. schůzi dne 18. 1. 1949, s. 8. V př́padě prodejů můžeme uvést např. odprodej ze zámků Chotoviny, Oselce, Červený Hrádek, Peruc, Doksy, Huttenhof, Falkenburk, Petrohrad, Slavice, Č́ížkovice, Dolní Krč, Jindřichovice, Křinec, Slavice, Svojšín, Loučeň, Mcely, Horka nad Sázavou, Valdštejnký palác, Košetice a Přestavlky knihkupectví Czerny v Praze. Jednalo se o výmět číající 10,5 tun za 48530 Kčs. Srov. NA ČR, SPS, kart. 34, Dopis NKK č. j. 4030/50 ze dne 11. 4. 1950 adresovaný NPF ve věci knižních konfiskátů.

${ }^{143}$ NA ČR, SPS-D, kart. 25, Seznam objektů ve správě NKK, popř. NKK najatých, které slouží jako sběrny stát. kult. majetku.

${ }^{144}$ Tamtéž, přehled objektů pro ministerstvo státní kontroly - výpis ze základ. kartot. lístků

${ }^{145}$ NA ČR, SPS, kart. 34, interní záznam V. Chaloupky s přepisem stanoviska Ref. IV. Jednotného národního výboru v Ústí n. L.

146 ÚDU AV ČR, OD, NKK, kart. X, Úřední záznam od J. Soukupa o způsobu nakládání se zámeckými knihovnami a zároveň srov. výše, kde J. Soukup vyjmenovává i další subjekty, kterým byly předány zámecké knihovny krátce po válce.

${ }^{147}$ Tamtéž, Zpráva o doposud vykonaných pracích v tř́dění knih a pořádání zámeckých knihoven.

${ }^{148}$ UHLÍKOVÁ 2019, s. 244.

${ }^{149}$ ÚDU, OD, NKK, kart. X, Zpráva o doposud vykonaných pracích v tř̌́dění knih a pořádání zámeckých knihoven.

150 Tamtéž.

${ }^{151}$ Tamtéž, Rámcové směrnice a operativní plán dalšího tř́idění knih ze svozů a pořádání zámeckých knihoven.

152 Tamtéž.

${ }^{153}$ VRCHOTKA 1984, s. 76-77.

${ }^{154}$ Tamtéž, s. 79.
} 
reformy a jelikož ve vztahu k soukromým zámeckým knihovnám státní aparát nedisponoval efektivními nástroji (resp. žádnými) k zásahům do jejich vlastnictví, skončila řada $\mathrm{z}$ nich $\mathrm{v}$ tuzemských či zahraničních aukčních síních, což z hlediska veřejného zájmu vedlo ke značným kulturním škodám. V druhé republice a protektorátu došlo v důsledku záboru pohraničí a podřízení se okupační správě nejen k dalším významným knižním ztrátám, ale opětovně i ke kulturní újmě v obecné rovině. Majetkový rozvrat způsobený válečnými událostmi se odrazil také do vývoje po květnu 1945 , kdy se na pořad dne dostaly procesy související se zabíráním pozemkového majetku, doplněné navíc o všudypřítomné retribuční kauzy a odsun německého obyvatelstva. Snahy státu o zhodnocení konfiskovaného „neprrátelského“ majetku se odrazily i do manipulace s knihovnami, které posloužily jak pro doplnění fondů veřejných knihoven, tak pro utržení státem ceněných devizový prostředků.

$\mathrm{V}$ prvních letech po válce se správa knižních fondů nesla ve znamení kompetenční nevyjasněnosti a sporů mezi jednotlivými zainteresovanými institucemi. Výzkum provenience fondů dotčených těmito mechanismy je limitován př́stupem jednotlivých organizací, personálními kapacitami i časovým tlakem, kdy noví nabyvatelé spěchali na převzetí nabytého majetku. Knihy tak byly přejímány a předávány státním institucím bez podrobného soupisu, měrnou jednotkou se staly vagony, auta, bedny, knihovní regály. Nadto většina soukromých knihoven, vyjímaje ty zámecké, nedisponuje zpravidla provenienčním znakem. Ve sledování správních mechanismů tohoto období tak autoři spatřují možné východisko pro nalezení původních vlastníků těchto knih. Knihy v tomto období nemůžeme chápat pouze jako nosiče informací, nebo předměty sběratelské vášně. Vzhledem k nejistému osudu dřívějších majitelů na ně musíme leckdy nahlížet jako na poslední upomínku jejich existence - at' jednotlivců, či institucí.

\section{Prameny:}

ABS, sbírka Správa vyšetřování StB - vyšetřovací spisy (V), arch. č. V-3571 MV.

ANK, NUK: Archiv Národní knihovny, Národní a universitní knihovna Praha, nezpr.

ANK, VZ: Archiv Národní knihovny, Výroční zprávy.

AUK, Matrika doktorů UK: Archiv Univerzity Karlovy, Matriky Univerzity Karlovy.

Dekret č. 5/1945 Sb.: Dekret presidenta republiky č. 5/1945 Sb. ze dne 19. května 1945, o neplatnosti některých majetkově-právnich jednání z doby nesvobody a o národní správě majetkových hodnot Němců, Mad'arů, zrádců a kolaborantů a některých organisací a ústavio.

Dekret č. 12/1945 Sb.: Dekret presidenta republiky č. 12/1945 Sb. ze dne 21. června 1945, o konfiskaci a urychleném rozdělení zemědělského majetku Němců, Mad'arü, jakož i zrádců a neprátel českého a slovenského národa.

Dekret č. 108/1945 Sb.: Dekret presidenta republiky č. 108/1945 Sb. ze dne 25. ř́ijna 1945, o konfiskaci nepřátelského majetku a Fondech národní obnovy.

NA ČR, MŠK: Národní archiv ČR, Ministerstvo školství a kultury, Praha, nezpr.
NA ČR, SPS: Národní archiv ČR, Státní památková správa, Praha.

NA ČR, SPS-D: Národní archiv ČR, Státní památková správa - Dodatky.

NA ČR, ZÚ: Národní archiv ČR, Zemský úřad Praha - oddělení církevní, nadační a školské.

Směrnice MV č. 1700-27/3-46-82-Vb/3: Směrnice MV č. 1799-27/3-46-82-Vb/3 ze dne 31. března 1946 Dekret čís. 108/45 Sb., o konfiskaci neprátelského majetku a Fondech národni obnovy - směrnice $k \oint \oint 1 a 2$ - citováno dle Konfiskace, správa a prevod neprátelského majetku: zákony, vyhlášky, smérnice a pokyny. Praha: Právní odbor osidlovacího úřadu a Fondu národní obnovy, 1947.

SOA Třeboň, Sbírka matrik: Státní oblastní archiv v Třeboni, Sbírka matrik Jihočeského kraje, 1587-1949 (1952), Farní úřad Radomyšl.

ÚDU AV ČR, OD, NKK: Ústav dějin umění Akademie věd ČR v. v. i, oddělení dokumentace, Národní kulturní komise. Vl. nař. č. 70/1945 Sb.: Vládní nařízení č. 70/1945 Sb. ze dne 3. září 1945, kterým se vydává statut Národního pozemkového fondu při ministerstvu zemédèlství.

Vl. nař. č. 45/1946 Sb.: Vládní nařízení č. 45/1945 Sb. ze dne 1. března 1946, kterým se vydává statut a jednací rád Fondi̊ národní obnovy.

Vyhl. č. 1213/46 Ú. 1.: Vyhláška osidlovacího úřadu a Fondu národní obnovy v Praze č. 1213/46 Ú. 1. ze dne 29. dubna 1946, již se stanoví, jak má býti naloženo s některými movitými věcmi hmotnými z nepřátelského majetku konfiskovaného podle dekretu presidenta republiky ze dne 25. ríjna 1945, č. 108 Sb., o konfiskaci nepř́telského majetku a Fondech národní obnovy.

Vyhl. č. 2141/46 Ú. 1.: Vyhláška osidlovacího úřadu a Fondu národní obnovy v Praze č. 2141/46 Ú. 1. ze dne 3. prosince 1946, jižz se stanoví, jak má býti naloženo s některými movitými věcmi hmotnými, konfiskovanými podle dekretu č. 108/1945 Sb., které jsou v úschově, opatrování, správě, detenci nebo v držbě osob fysických a právnických.

Vyhl. č. 2142/46 Ú. 1.: Vyhláška osidlovacího úřadu a Fondu národní obnovy v Praze č. 2142/46 Ú. 1. ze dne 3. prosince 1946, již se stanoví, jak má býti naloženo některými konfiskovanými movitými věcmi hmotnými ze skladišt'.

Vyhl. MŠO č. 125: Vyhláška ministra školství a osvěty č. 125 ze dne 27. ledna 1947, kterou se vydává organizační a jednaci ř́d Národní kulturní komise - citováno dle edice pramenů v UHLÍKOVÁ, Kristina. Národní kulturní komise 1947-1951. Praha: Artefactum, 2004, dokument II/4.8.

Výn. MŠO č. B-98503-III: Výnos MŠO č. B-98 503-III ze dne 28. dubna 1947 Směrnice ministerstva školství a osvěty určené osvětovým a knihovnickým inspektorům k provádění bodu b), odst. 3 \& 1 vyhlášky Osidlovacího úřadu a Fondu národni obnovy v Praze ze dne 3. prosince 1946, již se stanoví, jak má býti naloženo s některými konfiskovanými movitými věcmi hmotnými ze skladišt' - citováno dle Věstník Ministerstva školství a osvéty 3, 1947, sešit 10.

Zák. č. 61/1918 Sb. z. a n.: Zákon č. 61/1918 Sb. z. a n. ze dne 10. prosince 1918, jímž se zrušují šlechtictví, rády a tituly. Zák. č. 81/1920 Sb. z. a n.: Zákon č. 81/1920 Sb. z. a n. ze dne 30. ledna 1920 , kterým se vydávají po rozumu $\S-u 10$ zákona ze dne 16. dubna 1919, č. 215 Sb. z. a n., ustanovení 
o př́délu zabrané půdy a upravuje se právní poměr ku přidělené půdě (zákon př́iělový).

Zák. č. 215/1919 Sb. z. a n.: Zákon č. 215/1919 Sb. z. a n. ze dne 16. dubna 1919, o zabrání velkého majetku pozemkového. Zák. č. 118/1920 Sb. z. a n.: Zákon č. 118/1920 Sb. z. a n. ze dne 12. února 1920, o hospodaření na zabraném majetku pozemkovém.

Zák. č. 329/1920 Sb. z. a n.: Zákon č. 329/1920 Sb. z. a n. ze dne 8. dubna 1920, o prevzetí a náhradě za zabraný majetek pozemkový (zákon náhradový).

Zák. č. 137/1946 Sb.: Zákon č. 137/1946 Sb. ze dne 16. května 1946, o Národních kulturních komisích pro správu státního kulturního majetku.

\section{Literatura:}

\section{ČASOPIS ČESKOSLOVENSKÝCH KNIHOVNÍKU}

1926: Knižní aukce. Časopis československých knihovníků 5, 1926, č. 2-3, s. 51-52.

ČERNÁ 1946: ČERNÁ, Marie. Škody na československých knihovnách a archivech, válkou zaviněné. Knihovna. Časopis Svazu českých knihovníkủ 1, 1946, č. 10, s. 301-304. ČERNÝ 1952: ČERNÝ, Václav. Státní archiv zemědělský a oblastní archivy zemědělské. Archivní časopis 2, 1952, č. 1, s. 22-25.

ČERNÝ 1992: ČERNÝ, Václav. Paměti III (1945-1972). Brno: Atlantis, 1992.

DEJMEK 2018: DEJMEK, Jindřich. Zápas první Československé republiky o přežití a jeho vyústění v Mnichově (březen-záŕí 1938). In: DEJMEK, Jindřich et al. Československo. Déjiny státu. Praha: Libri, 2018, s. 256-257. DOLEŽAL 1996: DOLEŽAL, Jiří. Česká kultura za protektorátu: školství, písemnictví, kinematografie. Praha: Národní filmový archiv, 1996.

FRIEDRICH - BRZEZINSKI 1996: FRIEDRICH, Joachim Carl - BRZEZINSKI, Zbigniev. Die allgemeinen Merkmale der totalitären Diktatur. In: JESSE, Eckhard (ed.): Totalitarismus im 20. Jahrhundert: Eine Bilanz der internationalen Forschung. Baden-Baden: Nomos, 1996.

GRUND 1933: GRUND, Antonín. Dražba mikulovské knihovny. Lidové noviny 41, 1933, č. 602 (1. 12. 1933), s. 9. HÁLA 1948: HÁLA, Rudolf. Knižní aukce. Typografia. Odborná revue československých knihtiskařu a grafiku 51, č. 1-4, s. 35-36.

HOMOLOVÁ-JELÍNKOVÁ 2020: HOMOLOVÁ-JELÍNKOVÁ, Dita. Šlechta v proménách. Osudy aristokracie $v$ Československu $v$ letech 1918-1948. Praha: Nakladatelství Lidové noviny, 2020.

JANDEROVÁ - HAAS 1966: JANDEROVÁ, H. - HAAS, A. Státní pozemkový úřad-spisy všeobecné, 1. dílči inventár (1875) 1918-1935 (1949). Praha: Státní ústřední archiv, 1966. JANOUŠEK 1926: JANOUŠEK, Emanuel. Z Čsl. státního archivu zemědělského v Praze. Časopis archivní školy 3, 1926, s. 173-174.

JANOUŠEK 1931: JANOUŠEK, Emanuel. Činnost Československého státního archivu zemědělského. Časopis české archivni školy 8, 1931, s. 246-247.

JANOUŠEK 1933: JANOUŠEK, Emanuel. Osudy patrimoniálních archivů. Časopis české archivní školy 9, 1933 s. 46-64.
JANOUŠEK 1934: JANOUŠEK, Emanuel. Další zkušenosti z prohlídek patrimoniálních archivů. Časopis české archivni školy 11, 1934, s. 49-64.

JANOUŠEK 1934a: JANOUŠEK, Emanuel. Z Čsl. státního archivu zemědělského. Časopis české archivní školy 11, 1934, s. 190-192.

JANOUŠEK 1968: JANOUŠEK, Emanuel. Vznik a počátky zemědělského archivu. Kapitola z historie českého archivnictví. Archivní časopis 18, 1968, s. 147-180.

KAUCKÁ 2015: KAUCKÁ, Kristýna. „Nekrolog dietrichštejnské knihovny": osud mikulovské zámecké knihovny mezi dvěma světovými válkami. Praha 2015. Diplomová práce. Univerzita Karlova. Filozofická fakulta.

KNEIDL 1956: KNEIDL, Pravoslav. Ze zámeckých knihoven. Časopis Národního muzea. Praha 125, 1956, s. 168-171. KNEIDL 1997: KNEIDL, Pravoslav. Vzpomínky bibliotekáře a bibliofila Bohumíra Lifky. Praha: Spolek českých bibliofilů, 1997.

KNIHOVNA 1945: Stav evropských knihoven po válce. Knihovna. Časopis Svazu českých knihovniků 1, 1945, č. 1, s. $31-32$

KNIHOVNA 1945a: Veliký den českého knihovnictví. Zástupci českého knihovnictví u pana presidenta. Knihovna. Časopis Svazu českých knihovníků 1, 1945. č. 2, s. 49-50.

KNIHOVNA 1945b: Rozhodnutí Čestného soudu při Svazu českých knihovníků. Knihovna. Časopis Svazu českých knihovniku 1, 1945, č. 2, s. 71.

KNIHOVNA 1945c: Ztráty francouzských knihoven za války. Knihovna. Časopis Svazu českých knihovníkủ 1, 1945, č. 5 , s. 164 .

KOKEŠ 2018: KOKEŠ, Luboš. Josef Hrubý. In: BÍLÝ, Matěj - ANEV, Petr (edd.). Biografický slovnik vedoucích funkcionářu KSČ (1921-1989): A-K. Praha: ÚSTR, 2018, s. 480.

KREJČÍK 1920: KREJČÍK, Adolf Ludvík. Z československého státního archivu zemědělského v Praze. Český časopis historický 26, 1920, př́loha, s. 51-53.

KREJČÍK 1921: KREJČÍK, Adolf Ludvík. Československý státní archiv zemědělský. Brázda: revuální týdeník agrárního hnutí 2, 1921, č. 8, s. 3-12.

KREJČÍK 1922: KREJČÍK, Adolf Ludvík. Zámecké knihovny. Národní listy - Vzdělávací príloha Národních listů 62, 1922, č. 22, s. 9.

KREJČÍK 1924: KREJČÍK, Adolf Ludvík. Z Čsl. státního archivu zemědělského. Časopis archivní školy 2, 1924, s. 197.

KREJČÍK 1927: KREJČÍK, Adolf Ludvík. Z Čsl. státního archivu zemědělského v Praze, Časopis archivní školy 5, 1927, s. 209.

KREJČÍK 1928: KREJČÍK, Adolf Ludvík. Z Čsl. státního archivu zemědělského. Časopis archivní školy 6, 1928, s. $197-198$.

KREJČÍK 1929: KREJČÍK, Adolf Ludvík. Př́spěvky $k$ soupisu archivi velkých statki̊. Praha: Československá akademie zemědělská, 1929.

KREJČÍK 1937: KREJČÍK, Adolf Ludvík. Pozemková reforma a archivy velikých statků. Praha: ČSAZ, 1937.

KREJČOVÁ - VLČEK 2007: KREJČOVÁ, Helena VLČEK, Mario. Návraty paměti: deponáty židovského 
majetku v Uméleckopri̊myslovém museu v Praze. Šenov u Ostravy: Tilia, 2017.

KUKLÍK 2010: KUKLÍK, Jan. Znárodněné Československo: od znárodnění k privatizaci - státní zásahy do vlastnických a dalších majetkových práv v Československu a jinde v Evropě. Praha: Auditorium, 2010.

KUPROVÁ 2014: KUPROVÁ, Renata (ed.). Adolf Ludvík Krejčík. Paměti. Praha: Národní archiv, 2014.

LEDINSKÁ-MALÁ 1971: LEDINSKÁ-MALÁ, Hana. Zámecká knihovna v Děčíně a její likvidace. Knihovna: Vědeckoteoretický sborník 8. Praha: SPN, 1971, s. 57-78.

LEDINSKÁ 1974: LEDÍNSKÁ, Hana. Děčínská zámecká knihovna (Př́íspěvek k dějinám). In: Z minulostí Děčínska 2. Děčín: ONV, 1974, s. 194-214.

LIDOVÉ NOVINY 1924: Druhá aukce sbírek Pálffy. Lidové noviny 32, 1924, č. 599 (29. 11. 1924), s. 7.

LIDOVÉ NOVINY 1926: Bibliotheca Pálffyana. Lidové noviny 34, 1926, č. 126 (10. 3. 1926), s. 7.

LIFKA 1933: LIFKA, Bohumír. Prodeje zámeckých knihoven. Vitrinka. Časopis spolku českých bibliofilì 10, 1933, č. 4, s. 129-132.

LIFKA 1933a: LIFKA, Bohumír. Dietrichsteinská knihovna. Lidové noviny 41, 1933, č. 583 (21. 11. 1933), s. 9.

LIFKA 1934: Zámecké a palácové knihovny v Čechách. Praha: vlastním nákladem, 1934.

LIFKA 1934a: LIFKA, Bohumír. Dražba Dietrichsteinské knihovny z Mikulova. Marginalie. Věstník spolku českých bibliofili 8, 1934, s. 18-19.

LIFKA 1938: LIFKA, Bohumír. Knihovny v okupaci. Marginálie. Věstník Spolku českých bibliofili̊. Praha: Spolek Českých bibliofilů 12, 1938, s. 120-121.

MÖSTL 2009: MÖSTL, Roman. Roudnická lobkowiczká knihovna. Jazykově francouzské tisky do roku 1717. Diplomová práce. České Budějovice 2009. Jihočeská univerzita v Českých Budějovicích. Pedagogická fakulta.

OOSTERHUIS 1926: OOSTERHUIS Rutger Adolf Benthem. Komenského zápis V „Liber Amirocum“. Pedagogické rozhledy: věstník literárního a pedagogického odboru při Ústředním spolku jednot učitelských v Čechách 36, 1926, č. 6, s. 289-290.

PEKǍ̌ 1923: PEKA ̌̌, Josef. Omyly a nebezpečí pozemkové reformy. 3. vydání. Praha: Vesmír, 1923.

PETR 2003: PETR, Stanislav. Rukopisy zámecké knihovny Dietrichsteinů v Mikulově v knihovně Národního muzea v Praze. In: RADIMSKÁ, Jitka (ed.). K výzkumu zámeckých, měštanských a cirkevních knihoven: Čtenár a jeho knihovna (=Opera romanica 4). České Budějovice: PF JU, 2003.

PRŮCHA 2004: PRŮCHA, Václav. Poválečné sociální reformy. In: PRŮCHA, Václav et al. Hospodářské a sociálni dějiny Československa 1918-1992: I. dil období 1918-1945. Brno: Doplněk, 2004.

PRŮCHA 2009: PRŮCHA, Václav. Poválečné revoluční přeměny a obnova národního hospodářství (1945-1948). Vlastnické přeměny v letech 1945-1946. PRŮCHA, Václav et al. Hospodářské a sociálni dějiny Československa 1918 1992: 2. dil 1945-1992, 2009, s. 71-103.

REJHA 2017: REJHA, Adam. Hrad a zámek Frýdlant jako bezpečné úložiště kulturního majetku během druhé světové války. Fontes Nissae 18, 2017, č. 1, s. 19-33.
ŘEZNÍČEK 1945: ̌̌EZNÍČEK, Ladislav. Veřejná knihovna města Brna za okupace. Knihovna. Časopis Svazu českých knihovniků 1, 1945, č. 6, s. 183.

STROUHALOVÁ 2016: STROUHALOVÁ, Marcela. Knihy znovu nalezené. Konfiskované knihy po druhé světové válce ve správě $N K \check{C} R$. Praha: Národní knihovna ČR, 2016.

STROUHALOVÁ 2017: K pohybu knižních konfiskátů po roce 1945. Knihovna: knihovnická revue 28, 2017, č. 2, s. $5-19$.

STROUHALOVÁ 2017a: STROUHALOVÁ, Marcela. Hidden or forbidden? Remarkable history of the books stored in the Reserve Collections of the National Library of the Czech republic. Praha: Národní knihovna ČR, 2017.

STROUHALOVÁ 2020: STROUHALOVÁ, Marcela. K možnostem průzkumu provenience novodobých knižních fondů Národní knihovny České republiky. In: BUŠTA, Jaroslav et al. Osudy konfiskátů: výzkum provenience a problematika přesunů kulturního majetku v Československu na základě prezidentských dekretů. Praha: Artefactum, 2020, s. 205-218.

ŠIMEČEK - TRÁVNÍČEK 2014: ŠIMEČEK, Zdeněk TRÁVNÍČEK, Jiří. Knihy kupovati... Dějiny knižního trhu $v$ českých zemích. Praha: Academia, 2014.

ŠUMAN 2016: ŠUMAN, František. Prodej děčínské zámecké knihovny a její další osudy. In: Bibliotheca Antiqua 2016: sbornik z 25. konference, 9.-10. listopadu 2016. Olomouc: Vědecká knihovna v Olomouci, 2016, s. 104-109.

TOMAN 1924: TOMAN, Prokop. Aukce sbírek hraběte Jánoše Pálffyho. Drobné umění: revue pro umělecký prümysl, lidové umění a hračky 5, 1924, č. 7, s. 174.

TOMAN 1969: TOMAN, Prokop Hugo. Karel Zink osmdesátníkem. Lidová demokracie - orgán Československé strany lidové 25, 1969, č. 97 (25. 4. 1969), s. 5.

TOMEŠ 1999: TOMEŠ, Josef et al. Český biografický slovnik XX. století. II. dil K-P. Praha: Paseka - Petr Meissner, 1999.

TRIBUNA 1928: Z pražských aukčních síní. Müllerův salon. Tribuna 10, 1928, č. 108 (8. 5. 1928), s. 5.

TRIBUNA 1928a: Ze světa sběratelů. Tribuna 10, 1928, č. 245 (16. 10. 1928), s. 5.

UHLÍKOVÁ 2004: UHLÍKOVÁ, Kristina. Národní kulturní komise 1947-1951. Praha: Artefactum, 2004.

UHLÍKOVÁ 2019: UHLÍKOVÁ, Kristina (ed.). Konfiskované osudy: umělecké památky z německého majetku ziskaného československým státem a jejich severočeští majitelé. Praha: Artefactum, 2019.

VĚSTNÍK MINISTERSTVA ŠKOLSTVÍ A OSVĚTY 1947: Složení Národní kulturní komise pro správu státního kulturního majetku v zemi České a v zemi Moravskoslezské v Praze. Věstník ministerstva školství a osvěty 3, sešit 3 (15. 2. 1947), s. 53.

VRCHOTKA 1984: VRCHOTKA, Jaroslav. Třicet let správy zámeckých a hradních knihoven v ČSR. Sbornik Národního muzea v Praze: Acta Musei Nationalis Pragae, rada C-Literární historie 24, 1984, č. 2, s. 73-84.

ZEIBRDLICH 1931: ZEIBRDLICH, Josef (ed.). Společenský adresář československý. Praha 1931. 


\section{Internetové zdroje:}

Akademie věd České republiky (AV ČR, v. v. i.) [online]. Botanický ústav AV ČR, v. v. i. - zámek Průhonice. [Cit. 20. 6. 2020] Dostupné z:

http://www.pruhonickypark.cz/cs/zamek/historie-zamku/ ART+: vše o trhu s uměním - prehled historie pražských aukci 1912-1939 [online]. [Cit. 15. 3. 2020]. Dostupné z: https://www.artplus.cz/cs/aukcni-zpravodajstvi/1/z-historie-prazskych-aukci

Slovnik českých nakladatelstvi 1849-1949 [online]. Heslo Karel Zink. [Cit. 20. 6. 2020]. Dostupné z: https://www.slovnik-nakladatelstvi.cz/nakladatelstvi/karel-zink.html

Provenio - Virtuální rekonstrukce knižních celků [online].

Knihovna Národního muzea. Heslo roudnická lobkowiczská knihovna. [Cit. 30. 11. 2020]. Dostupné z: https://provenio. net/records/ab36e2d8-ea5d-46ee-a43c-26848c3fd593.

Společná česko-slovenská digitální parlamentni knihovna [online]. Poslanecká sněmovna parlamentu České republiky. Důvodová zpráva k zákonu č. 137/1946 Sb. o NKK, Tisk NS T.344. [Cit. 1.12.2020]. Dostupné z: https://www.psp.cz/ eknih/1945pns/tisky/t0344_00.htm

\author{
Marcela Sulženko \\ | Luboš Kokeš \\ Národní knihovna České republiky \\ Klementinum 190 \\ 11000 Praha
}

